\title{
Merostachys Spreng. (Poaceae: Bambusoideae: Bambuseae: Arthrostylidiinae) na Mata Atlântica do Estado de Minas Gerais, Brasil
}

\author{
$\underline{\text { Ronaldo Vinícius-Silva }}^{1,3}$, Daniele de Freitas Parma ${ }^{1}$, Cristielle de Jesus-Costa ${ }^{1}$, Lynn G. Clark ${ }^{2}$ e \\ Ana Paula Santos-Gonçalves ${ }^{1}$
}

Recebido: 17.05.2017; aceito: 18.12.2017

\begin{abstract}
Merostachys Spreng. (Poaceae: Bambusoideae: Bambuseae: Arthrostylidiinae) from the Atlantic Forest of Minas Gerais State, Brazil). This work consists of a floristic survey of the Merostachys species (Bambusoideae: Arthrostylidiinae) from the Atlantic Forest of Minas Gerais State. It is based on collections of botanical material in Conservation Units and private properties, and on the analysis of specimens from national and foreign herbaria. Twentytwo taxa were cataloged. Merostachys leptophylla and M. calderoniana were recorded for the first time in the state; $M$. tatianae, M. espessa, M. fimbriolaminata, M. ramosa and M. ximenae are, to date, registered only for Minas Gerais. An identification key to the cataloged taxa, illustrations and comments about morphology, reproductive cycle, habitat and geographic distribution are presented.
\end{abstract}

Keywords: floristic, morphology, neotropical woody bamboos

RESUMO - (Merostachys Spreng. (Poaceae: Bambusoideae: Bambuseae: Arthrostylidiinae) na Mata Atlântica do Estado de Minas Gerais, Brasil). Este trabalho consiste em um estudo florístico das espécies de Merostachys Spreng. (Bambusoideae: Arthrostylidiinae) ocorrentes na Mata Atlântica do Estado de Minas Gerais, e foi realizado com base em coletas de material botânico em Unidades de Conservação e propriedades particulares, além da análise de espécimes depositados em herbários nacionais e estrangeiros. Foram catalogados 22 táxons. Merostachys leptophylla e M. calderoniana foram registradas no Estado pela primeira vez no presente estudo; M. tatianae, M. espessa, M. fimbriolaminata, M. ramosa e M. ximenae são, até agora, registradas apenas para o Estado de Minas Gerais. São apresentadas chave de identificação, descrições e ilustrações, bem como comentários sobre morfologia, ciclo reprodutivo, habitat e distribuição geográfica das espécies.

Palavras-chave: bambus lenhosos neotropicais, florística, morfologia

\section{Introdução}

Merostachys Spreng. é um dos gêneros mais diversos pertencente à subtribo Arthrostylidiinae, com 53 espécies descritas (Bamboo Phylogeny Group 2012, Santos-Gonçalves et al. 2012, Tyrrell et al. 2012, Parma et al. 2016a, Vinícius-Silva et al. 2016). As espécies do gênero estão distribuídas desde o México até o sul do Brasil, e têm a costa Atlântica do Brasil como o centro de diversidade e endemismo (Judziewicz et al. 1999).

Apesar de o gênero ser facilmente reconhecido morfologicamente (McClure 1973, Judziewicz et al. 1999), existem inúmeras espécies de difícil delimitação. Fatores como a escassez de coletas e exsicatas com espécimes pouco representativos, juntamente com longos ciclos reprodutivos, comum entre os bambus lenhosos (Janzen 1976), dificultam a identificação dessas espécies. Em Merostachys, o ciclo reprodutivo tem duração de aproximadamente 30-50 anos, fator este que, provavelmente, contribui para a escassez de espécimes férteis nos herbários (Janzen 1976, Guilherme \& Ressel 2001, Liebsh \& Reginato 2009, Guerreiro 2014).

Diante destas dificuldades, estudos florísticotaxonômicos mais abrangentes são indispensáveis, de modo a fornecer subsídios para a revisão taxonômica e estudos filogenéticos futuros. Até o momento,

1. Universidade Federal de Viçosa, Centro de Ciências Biológicas e da Saúde, Departamento de Biologia Vegetal, CCB2, $3^{\circ}$ andar 36570-900, Viçosa, MG, Brasil

2. Iowa State University, Department of Ecology, Evolution, and Organismal Biology, 251 Bessey Hall, Ames, Iowa 50011-1020, U.S.A.

3. Autor para correspondência: ronaldovinybio@yahoo.com.br 
existem poucos estudos taxonômicos exclusivos para Merostachys (Sendulsky, 1992, 1995, 1997, 2001, Lizarazu et al. 2011). O que se encontra são resultados provindos de pesquisas com a família Poaceae, com a subfamília Bambusoideae ou com a tribo Bambuseae (McClure \& Smith 1967, Smith et al. 1982, Teixeira et al. 2007, Viana \& Filgueiras 2008, Schmidt \& Longhi-Wagner 2009, Greco 2013, Shirasuna \& Filgueiras 2013).

O presente estudo teve como objetivo catalogar as espécies de Merostachys ocorrentes na Mata Atlântica do Estado de Minas Gerais. São fornecidas chave de identificação, ilustrações e descrições, além de comentários sobre morfologia, ciclo reprodutivo, hábitat e distribuição geográfica.

\section{Material e métodos}

Foram realizadas expedições a campo, entre março e novembro de 2014 e junho de 2016, para coleta de material botânico em porções de Mata Atlântica de Minas Gerais (figura 1), especificamente nas seguintes Unidades de Conservação: Parque Estadual Alto

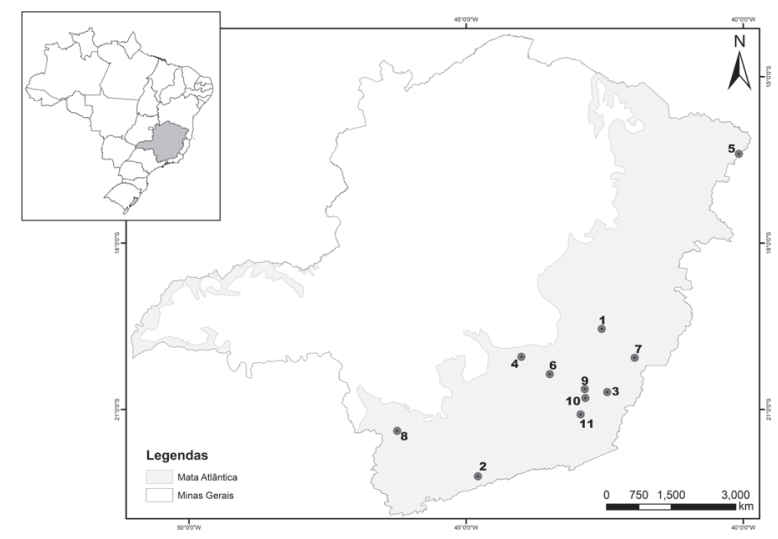

Figura 1. Mapa do Brasil com destaque o Estado de Minas Gerais, evidenciando a Mata Atlântica e os pontos de coleta. 1. Parque Estadual do Rio Doce. 2. Parque Estadual Serra do Papagaio. 3. Parque Estadual Serra do Brigadeiro. 4. Parque Estadual Serra do Rola Moça. 5. Parque Estadual Alto Cariri. 6. APA das Andorinhas. 7. RPPN Mata do Sossego. 8. RPPN Fazenda Lagoa. 9. Estação de Pesquisa, Treinamento e Educação Ambiental Mata do Paraíso. 10. Munícipio de Viçosa. 11. Município de Ubá.

Figure 1. Map of Brazil highlighting Minas Gerais State, showing the Atlantic Forest and the collection sites. 1. Parque Estadual do Rio Doce. 2. Parque Estadual Serra do Papagaio. 3. Parque Estadual Serra do Brigadeiro. 4. Parque Estadual Serra do Rola Moça. 5. Parque Estadual Alto Cariri. 6. APA das Andorinhas. 7. RPPN Mata do Sossego. 8. RPPN Fazenda Lagoa. 9. Estação de Pesquisa, Treinamento e Educação Ambiental Mata do Paraíso. 10. Municipality of Viçosa. 11. Municipality of Ubá.
Cariri, Parque Estadual da Serra do Papagaio, Parque Estadual da Serra do Rola Moça, Parque Estadual do Rio Doce, Parque Estadual da Serra do Brigadeiro, APA Cachoeira das Andorinhas, RPPN Fazenda Lagoa, RPPN Mata do Sossego e Estação de Pesquisa, Treinamento e Educação Ambiental Mata do Paraíso e em propriedades particulares nos municípios de Ouro Preto, Ubá e Viçosa. O material foi coletado e processado de acordo com Soderstrom \& Young (1983) e posteriormente identificado e depositado no Herbário VIC da Universidade Federal de Viçosa; duplicadas serão enviadas para alguns herbários nacionais e estrangeiros. Adicionalmente, foram analisadas as coleções dos herbários: BHCB, CEPEC, CESJ, ESAL, G, IAC, ICN, ISC, K, MO, NY, OUPR, P, RB, SP, UB, UEC, US e VIC (acrônimos de acordo com Thiers, 2016).

A identificação dos espécimes foi realizada por meio da literatura especializada (Sendulsky 1992, 1995, 1997, 2001), consulta aos Opus Princeps e análise dos materiais-tipo. As espécies foram descritas seguindo a terminologia morfológica adotada em McClure (1966) e Judziewicz et al. (1999). As estruturas vegetativas e reprodutivas foram analisadas com o auxílio de microscópio estereoscópico e as mensurações realizadas com paquímetro, régua e papel milimetrado.

\section{Resultados e Discussão}

Merostachys encontra-se representado na Mata Atlântica de Minas Gerais por 22 táxons. Destes, 16 confirmados em nível específico, para os quais foram apresentadas descrições completas. Os demais foram designados como aff. devido a insuficiência de informações no momento, que permitam a segura identificação deste espécimes, uma vez que são conhecidos apenas em estádio vegetativo ou por poucas ou únicas coletas. Para estes táxons são apresentadas descrições diagnósticas.

Além disso, também é aqui apresentada uma descrição para o gênero. A descrição do gênero, assim como da maioria das espécies, foi baseada em estados de caracteres provenientes tanto de espécimes encontrados em Minas Gerais quanto em outros Estados. A inclusão de materiais não provenientes de Minas Gerais nas descrições de certas espécies está relacionada ao fato dos espécimes coletados no Estado não estarem em estádio reprodutivo. Características tais como: o diâmetro dos ramos do complemento de ramo; a presença de uma faixa infranodal de tricomas; 
a ocorrência de uma faixa de tricomas estrigosos antrorsos na face abaxial da lâmina das folhas dos ramos em direção ao ápice, próxima à estria discolor; a presença de um tufo de tricomas híspidos na base da face abaxial da lâmina das folhas dos ramos, comprimento da espigueta e número de antécios por espigueta foram as que apresentaram maior valor taxonômico para as espécies investigadas neste estudo.

Merostachys Spreng., Syst. Veg. 1: 132, 249. 1824.

Plantas escandentes ou arborescentes com colmos inicialmente eretos e posteriormente arqueando-se no ápice ou inclinando-se sobre a vegetação. Rizomas paquimorfos. Colmos fistulosos ou raramente preenchidos por medula. Folhas do colmo com lígula interna presente; lâmina pseudopeciolada, reflexa a subreflexa. Gema única no nó do mediocolmo, que se desenvolve em uma estrutura basal de formato apsidado (meristema "fan-shaped"). Complementos de ramo com poucos a muitos ramos; ramos de segunda ordem às vezes presente. Folhas dos ramos com lígula externa e interna; lígula externa com ápice ciliado; lígula interna membranácea, ápice ciliado; fímbrias presentes ou ausentes; lâmina lanceolada a oval lanceolada, margem escabra, ápice acuminado. Inflorescência terminal, racemosa, portando espiguetas rudimentares no ápice. Espiguetas 1-2(-10)-flora; glumas 2, desiguais; lema multinervado; pálea constituinda por duas quilhas, quilhas ciliadas em direção ao ápice; extensão da ráquila com antécio rudimentar no ápice. Lodículas 3. Androceu com 3 estames. Gineceu com 2 estigmas híspidos a subplumosos; ovário glabro. Fruto do tipo cariopse nucóide.

Chave de identificação para as espécies de Merostachys ocorrentes na Mata Atlântica de Minas Gerais

1. Fímbrias das folhas dos ramos ausentes.... M. fistulosa

1. Fímbrias das folhas dos ramos presentes

2. Fímbrias das folhas dos ramos fusionadas M. fimbriolaminata

2. Fímbrias das folhas dos ramos não fusionadas

3. Faixa infranodal de tricomas presente

4. Nós do colmo e dos ramos proeminentes e de formato anelar M. ximenae

4. Nós do colmo e dos ramos não proeminentes e sem formato anelar

5. Entrenós com formato subtriangular, ramos de segunda ordem presentes ...... Merostachys aff. speciosa

5. Entrenós com formato cilíndrico, ramos de segunda ordem ausentes

6. Ramos do complemento de ramo 3-7 mm de diâmetro

7. Entrenós verde-amarelados sem estrias, glabros; fímbrias das folhas dos ramos $0,1-2,7 \mathrm{~mm}$ compr.; espiguetas solitárias, 1-2 flora

M. riedeliana

7. Entrenós amarelos com estrias verdes, escabros; fímbrias das folhas dos ramos 4,7-7 mm compr.; espiguetas aos pares ou em tríades, 1-flora M. ternata

6. Ramos do complemento de ramo 0,6-2 mm de diâmetro

8. Face abaxial da lâmina das folhas dos ramos com uma faixa de diminutos tricomas estrigosos antrorsos em direção ao ápice, próxima à estria discolor

9. Entrenós glabros, lustrosos; face adaxial da lâmina das folhas dos ramos com 2-4 nervuras marginais escabras, região marginal oposta com diminutos tricomas estrigosos antrorsos em direção ao ápice M. fischeriana

9. Entrenós escabros, opacos; face adaxial da lâmina das folhas dos ramos com 3 nervuras marginais escabras, região marginal oposta glabra, sem diminutos tricomas estrigosos antrorsos em direção ao ápice Merostachys aff. petiolata

8. Face abaxial da lâmina das folhas dos ramos sem uma faixa de diminutos tricomas estrigosos antrorsos em direção ao ápice, próxima à estria discolor

10. Face abaxial da lâmina das folhas dos ramos sem um tufo de tricomas híspidos na base

11. Ramos do complemento de ramo ca. $1,8 \mathrm{~mm}$ de diâmetro; espiguetas 10-14 mm compr. M. claussenii var. mollior 11. Ramos do complemento de ramo 0,55-1,2 mm de diâmetro; espiguetas 4-8 mm compr. 12. Entrenós glabros, lustrosos; inflorescências com pedúnculo subtendido pela 
bainha da última folha do ramo; espiguetas 1-flora ..... Merostachys aff. fischeriana

12. Entrenós glabros a escabros, opacos; inflorescências com pedúnculo exposto; espiguetas 1-2-flora M. exserta

10. Face abaxial da lâmina das folhas dos ramos com um tufo de tricomas híspidos na base

13. Ramos do complemento de ramo 0,9-1,3 mm de diâmetro; espiguetas 10-11 mm de compr. M. skvortzovii

13. Ramos do complemento de ramo 1,5-2 $\mathrm{mm}$ de diâmetro; espiguetas 12-17 mm de compr. M. claussenii var. claussenii

3. Faixa infranodal de tricomas ausente

14. Aurículas nas folhas dos ramos presentes M. calderoniana

14. Aurículas nas folhas dos ramos ausentes

15. Face abaxial da lâmina das folhas dos ramos com um tufo de tricomas híspidos na base

16. Complementos de ramo com $125-850$ ramos M. ramosa

16. Complementos de ramo com 13-87 ramos

17. Entrenós híspidos, cobertos por tricomas urentes M. tatianae

17. Entrenós glabros, seríceos ou escabros

18.Entrenós verde- amarelados; nós do colmo e dos ramos proeminentes; gluma II constituindo um ângulo agudo em relação à raque ..... M. brevigluma

18. Entrenós verdes com estrias amarelas; nós do colmo e dos ramos não proeminentes; gluma II constituindo um ângulo obtuso em relação à raque .... Merostachys aff. riedeliana

15. Face abaxial da lâmina das folhas dos ramos sem um tufo de tricomas híspidos na base 19. Entrenós glabros, parede dos entrenós $0,5-1 \mathrm{~mm}$ de espessura; ramos do complemento de ramo 0,5-0,9 mm de diâmetro M. leptophylla

19. Entrenós escabros, parede dos entrenós 1,07-5 mm de espessura; ramos do complemento do ramo 1,15-3 mm de diâmetro

20. Ramos dos complementos de ramo 2,5-3 mm de diâmetro, lúmen do entrenó por

vezes preenchido por medula (colmo cheio) M. espessa

20. Ramos dos complementos de ramo 1,1-2,3 mm de diâmetro, lúmen do entrenó nunca preenchido por medula

21. Franja de tricomas na linha nodal presente; inflorescências não pectinadas, espiguetas 8,5-9 mm de compr., agrupadas aos pares ou em tríades, às vezes solitárias Merostachys aff. burmanii

21. Franja de tricomas na linha nodal ausente; inflorescências pectinadas, espiguetas 13-16 mm compr., solitárias Merostachys aff. fistulosa 1. Merostachys brevigluma Send., Kew Bulletin 56(3): 629. 2001.

Figura 2

Plantas arborescentes com colmos inicialmente eretos e arqueando-se no ápice. Colmos 8-10 m compr. Entrenós 58-62 cm compr., cilíndricos, 0,9-1,6 cm diâm., verde-amarelados, glabros a escabros, opacos; faixa infranodal de tricomas ausente; lúmen amplo, não preenchido por medula; parede 1,25-2,25 mm de espessura. Nós proeminentes, castanhos; franja de tricomas na linha infranodal ausente. Folhas do colmo 21,8-38,8; bainha 18,3-31,5 × 4,7-10 cm, face adaxial glabra, brilhante, face abaxial glabra a levemente escabra, esparsamente serícea, margem sobreposta ciliada; lígula interna 1-1,5 mm compr., membranácea, pubescente, ápice ciliado; fímbrias presentes, não fusionadas, 1-3,5 mm compr., retas a sinuosas, amareladas; lâmina 3,6-8,6 × 0,4-0,8 cm, face adaxial híspida, face abaxial escabra no ápice, glabra no restante, margem escabra. Complementos de ramo com 65-86 ramos, 20-65,5 cm compr., 1,5-2,5 mm diâm.; ramos de segunda ordem ausentes; nós proeminentes, castanhos. Folhas dos ramos 3-11 por ramo; bainha 2,5-15,7 $\mathrm{cm} \times 1,7-5,5 \mathrm{~mm}$, glabra a pubescente; aurículas ausentes; lígula externa 0,1-0,3 mm compr.; lígula interna 0,6-2 mm compr., pubérula a pubescente; fímbrias presentes, não fusionadas, 1-5 mm compr., a maioria decídua, retas a sinuosas, amareladas a avermelhadas; pseudopecíolo 2,5-4,5 mm compr., castanho, retorcido, glabro a 


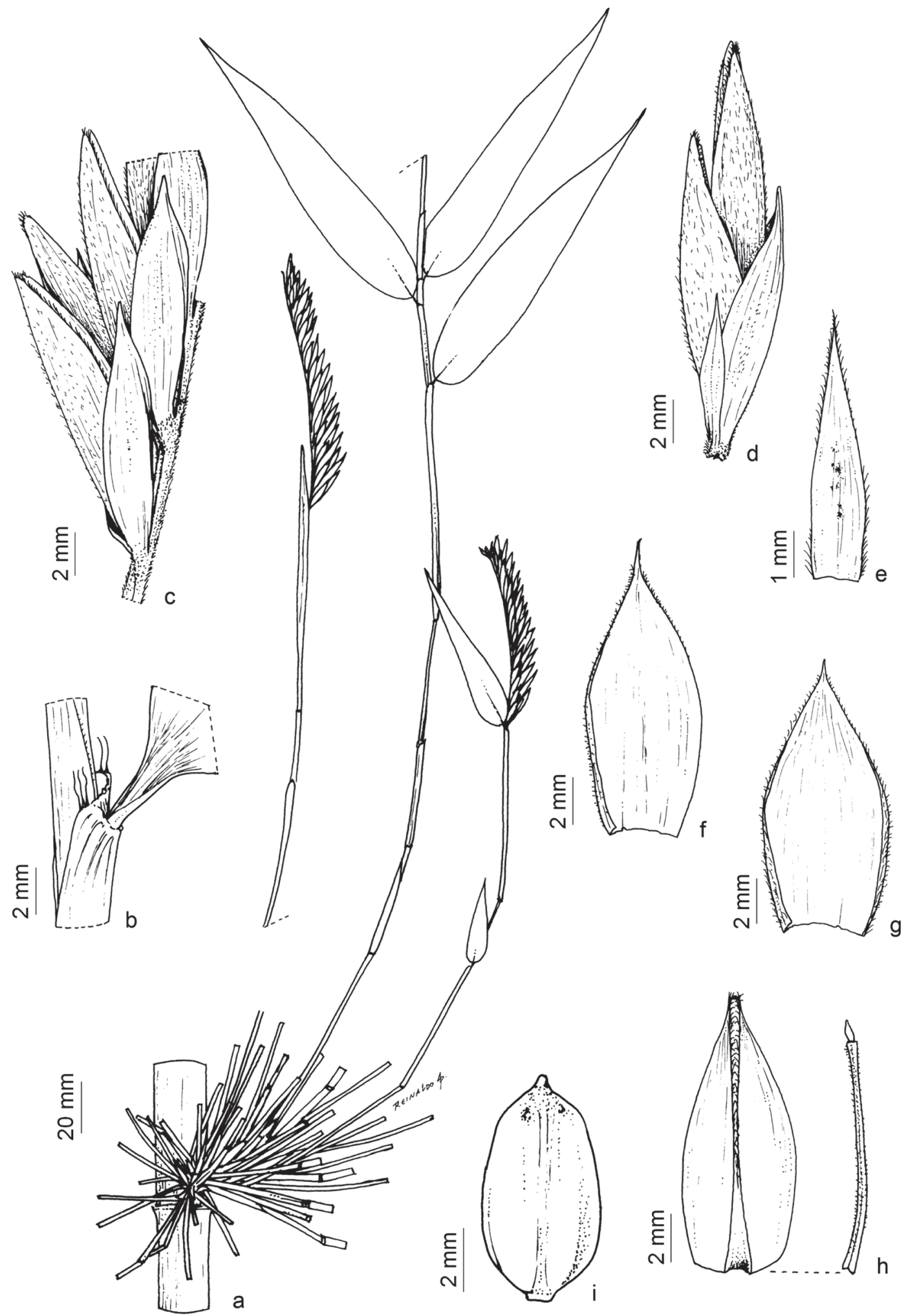

Figura 2. Merostachys brevigluma. a-g. (Bacherman s.n. SP169274). a. Complemento de ramo com folhas dos ramos. b. Região ligular da folha do ramo e fímbrias. c. Seção da inflorescência. d. Espigueta. e. Gluma I, f. Gluma II. g. Lema. h. Pálea e extensão da ráquila. i. (Windisch 2788). Cariopse. (Ilustrada por Reinaldo Pinto).

Figure 2. Merostachys brevigluma. a-g. (Bacherman s.n. SP169274). a. Branch complement with foliage leaves. b. Ligular region of foliage leaf and fimbriae. c. Section of the inflorescence. d. Spikelet. e. Lower glume. f. Upper glume. g. Lemma. h. Palea and rachilla extension. i. (Windisch 2788). Caryopsis. (Illustrated by Reinaldo Pinto). 
pubérulo; lâmina 5-14 × 1-3 cm, C:L $=4,5-6,5$, lanceolada, face adaxial com 2-3 nervuras marginais escabras em direção ao ápice, glabra no restante, face abaxial com um tufo de tricomas híspidos na base, ápice escabro, glabra no restante, base simétrica a assimétrica. Inflorescência pectinada, 4,5-14 cm compr., 12-33 espiguetas; pedúnculo subtendido pela bainha da última folha do ramo; raque velutina a tomentosa, bráctea estéril na base do racemo ausente. Espiguetas 12,5-16 × 3-4 mm, solitárias, 1-2-flora; pedicelo 1-2 mm compr., tomentoso; gluma I 3-8 $\times$ 1-1,5 mm, 1-nervada, pubescente, margem ciliada apicalmente, ciliada desde a base em um dos lados, aristada, arista 0,5-1 mm compr.; gluma II 9-13,5 × 3,5-5,5 mm, 8-11-nervada, pubescente a serícea, nervura central minuciosamente escabra no ápice, margem ciliada apicalmente, ciliada desde a base em um dos lados, aristada, arista 0,5-1,5 $\mathrm{mm}$ compr., ângulo agudo entre gluma II e raque; lema 10-13,5 × 6-7,5 mm, 11-13-nervado, opaco, esparsamente seríceo, margem apical com uma franja de tricomas, sem manchas escuras adaxialmente, mútico a aristado, arista ca. 1,5 $\mathrm{mm}$ compr.; pálea 10-14 × 4,5-6 mm, 10-12-nervada, opaca, ápice e região próxima à quilha pubescente, pubérula no restante, margem ciliada apicalmente; extensão da ráquila 8-13 mm compr. Cariopse 6,5-8 × 3,5-4 mm, oval, rostrada, castanho-claro, hilo conspícuo.

Material examinado: BRASIL. MinAs Gerais: Delfim Moreira, São Francisco dos Campos, 8-VI-1950, fl., M. Kuhlmann 2453 (Type) (MO, SP, US).

Material adicional examinado: BRASIL. SÃo PAULo: Campos do Jordão, Alto da Ferradura, 4-I-1981, fl., fr., W. Bacherman s.n. (Type) (SP169274, US2926643); idem, Serra da Mantiqueira, Serra dos Alpes, 14-V-1980, fl., P.G. Windisch 2788 (Type) (ICN).

Merostachys brevigluma está inclusa no "Grupo M. speciosa" (Sendulsky 2001) e, em Minas Gerais, caracteriza-se por apresentar colmo com entrenós verde-amarelados, nós dos ramos proeminentes, lâminas das folhas dos ramos glabras, com um tufo de tricomas híspidos na base, fímbrias das folhas dos ramos geralmente decíduas e gluma II formando um ângulo agudo com a raque.

Fenologia de floração: Esta espécie foi coletada com flor em 1948, 1949, 1950, 1980 e 1981, o que sugere um ciclo reprodutivo de, aproximadamente, 30 anos.

Distribuição: Merostachys brevigluma distribui-se por São Paulo e Minas Gerais, onde é encontrada na Serra da Mantiqueira (Sendulsky 2001), em subbosque e borda de vegetação caracterizada por Veloso et al. (1991) como Floresta Atlântica Estacional Semidecidual Montana.

2. Merostachys calderoniana Send., Novon 7 (3): 290. 1997.

Figura 3

Plantas escandentes. Colmos 4-8 m compr. Entrenós 14-40 cm compr., cilíndricos, 0,5-1,4 cm diâm., verde-amarelados, glabros, opacos, geralmente cobertos por uma camada de cera branca; faixa infranodal de tricomas ausente; lúmen amplo, não preenchido por medula; parede 0,4-1,5 mm de espessura. Nós não proeminentes, castanhos; franja de tricomas na linha nodal ausente. Folhas do colmo 6,5-24 cm compr.; bainha 5-15,5 $\times 1-3,5 \mathrm{~cm}$, face adaxial glabra, brilhante, face abaxial glabra, geralmente coberta por uma camada de cera branca, margem sobreposta ciliada; lígula interna 0,1-1 mm compr., membranácea, pubescente, ápice ciliado; fímbrias presentes, não fusionadas, $0,65-11 \mathrm{~mm}$ compr., encaracoladas, amareladas a castanhas, geralmente castanhas na base e amareladas em direção ao ápice; lâmina 1,5-8,5 × 0,2-0,8 cm, face adaxial escabra, face abaxial glabra, ambas as faces geralmente cobertas por uma camada de cera branca, margem escabra. Complementos de ramo com 8-45 ramos, 11-34,5 cm compr., ca. 1,5 mm diâm.; ramos de segunda ordem ausentes; nós não proeminentes, castanhos. Folhas dos ramos 5-16 por ramo; bainha $1,5-4 \mathrm{~cm} \times 1,5-4 \mathrm{~mm}$, glabra a pubescente, por vezes hirsuta ou tomentosa próximo à margem sobreposta, margem sobreposta ciliada; aurículas presentes, 0,1-1 mm compr.; lígula externa $0,1-0,3 \mathrm{~mm}$ compr.; lígula interna 0,2-0,7 mm compr., pubescente; fímbrias presentes, não fusionadas, 2-17 mm compr., encaracoladas, geralmente dispostas em todas as direções, amareladas a castanhas, às vezes prateadas, geralmente castanhas na base e amareladas ou prateadas em direção ao ápice; pseudopecíolo 1,5-4,5 mm compr., castanho, reto a retorcido, pubescente a híspido; lâmina 5-19,5 $\times 1-2 \mathrm{~cm}, \mathrm{C}: \mathrm{L}=5-11$, lanceolada, face adaxial com 2-3 nervuras marginais escabras, região marginal oposta com diminutos tricomas estrigosos, glabra no restante, face abaxial com uma faixa de diminutos tricomas estrigosos antrorsos próxima à estria discolor, glabra no restante ou ocasionalmente completamente coberta por tricomas estrigosos, base assimétrica. Inflorescência pectinada, 5-10 cm compr., 11-18 


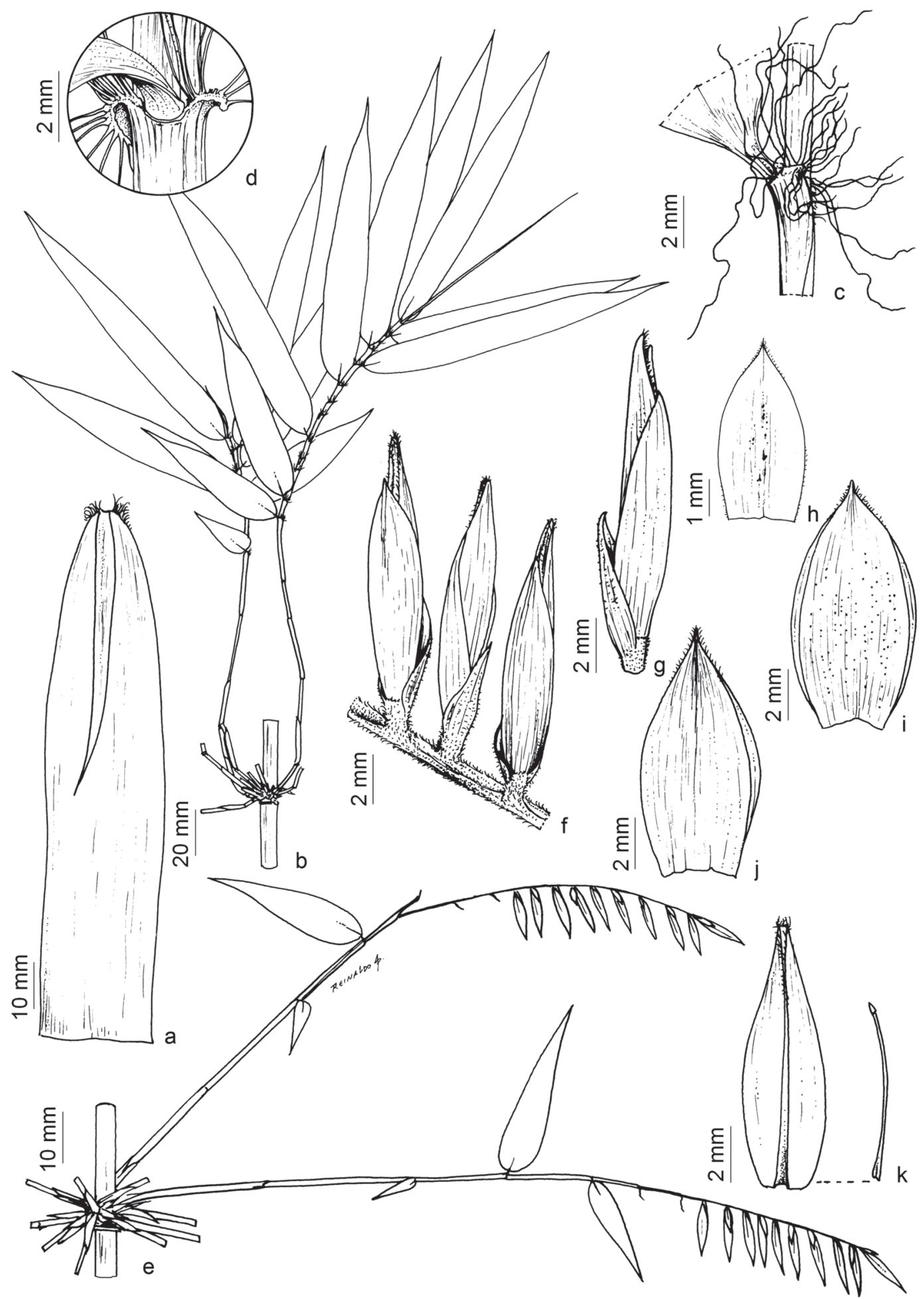

Figura 3. Merostachys calderoniana. a. (R.V. Silva \& Cupertino 17). b-d. (Santos-Gonçalves et al. 168). e-k. (Lima et al. 204). a. Folha do colmo. b. Complemento de ramo com ramos vegetativos e folhas. c. Região ligular da folha do ramo com fímbrias encaracoladas. d. Aurículas. e. Complemento de ramo com ramos floríferos. f. Seção da inflorescência. g. Espigueta. h. Gluma I. i. Gluma II. j. Lema. k. Pálea e extensão da ráquila. (Ilustrada por Reinaldo Pinto).

Figure 3. Merostachys calderoniana. a. (R.V. Silva \& Cupertino 17). b-d. (Santos-Gonçalves et al. 168). e-k. (Lima et al. 204). a. Culm leaf. b. Branch complement with vegetative branches and leaves. c. Ligular region of the foliage leaf with curly fimbriae. d. Auricles. e. Branch complement with floriferous branches. f. Section of the inflorescence. g. Spikelet. h. Lower glume. i. Upper glume. j. Lemma. k. Palea and rachilla extension. (Illustrated by Reinaldo Pinto). 
espiguetas; pedúnculo subtendido pela bainha da última folha do ramo; raque velutina, bráctea estéril na base do racemo ausente. Espiguetas 11,5-14 $\times 2 \mathrm{~mm}$, solitárias, 1-flora; pedicelo 1-1,5 mm compr., velutino; gluma I 5,5-6 × 2,5-3,5 mm, 5-7-nervada, pubescente, margem ciliada, manchas escuras adaxialmente, mucronada; gluma II 10-10,5 × 5-6 mm, 13-15-nervada, pubérula a pubescente, margem ciliada apicalmente, mucronada, ângulo obtuso entre gluma II e raque; lema 10-11 × 5-6 mm, 15-18-nervado, brilhante, pubérulo próximo à margem e no ápice, glabro no restante, ápice com uma franja de tricomas, sem manchas escuras adaxialmente, mucronado; pálea 9-10 $\times$ 4-5 mm, 10-nervada, brilhante, glabra, margem ciliada apicalmente; extensão da ráquila $6-8 \mathrm{~mm}$ compr. Cariopse não vista.

Material examinado: BRASIL. Minas Gerais: Marliéria, Parque Estadual do Rio Doce, Trilha da Campolina, 14-IV-2014, veg., R.V. Silva \& M.A. Cupertino 17 (VIC); Idem, Trilha da Lagoa Preta, 26-VI-1999, veg., A.P. Gonçalves et al. 168 (VIC).

Material adicional examinado: BRASIL. BAHIA: Cachoeira, Estrada da Adutora da Barragem Pedra do Cavalo, 11-XI-1983, fl., J.C.A. Lima et al. 204 (HRB); Una, rodovia Una-Olivença, $20 \mathrm{Km} \mathrm{N}$ de Una, 27-IV1976, veg., C.E. Calderón, T.S. Santos \& L.B. Oliveira 2400 (Type) (CEPEC, US). Espírito SANTo: Ibiraçu, Estação Ecológica do Morro da Vargem, 26-V-1990, veg., H.Q. Boudet Fernandes, J.M.L. Gomes, A.L. Martins et al. 2928 (VIC).

Merostachys calderoniana assemelha-se a $M$. leptophylla pela presença, em ambas as espécies, de uma camada de cera branca no entrenó, e por apresentar antécio com lema e pálea glabros e brilhantes. No entanto, difere principalmente pela presença, em $M$. calderoniana, de aurículas nas folhas dos ramos, pelo comprimento e largura da lâmina das folhas dos ramos e por apresentar fímbrias encaracoladas.

Fenologia de floração: a espécie foi registrada fértil em 1983, 1996 e 2004, não sendo possível estimar seu ciclo reprodutivo.

Distribuição: Merostachys calderoniana é registrada para a Bahia (Sendulsky 1997) e Espírito Santo (Flora do Brasil 2020). É aqui citada, pela primeira vez, para Minas Gerais, onde é encontrada em subbosque e borda de vegetação caracterizada por Veloso et al. (1991) como Floresta Atlântica Estacional Semidecidual Submontana.
3. Merostachys claussenii Munro, Trans. Linn. Soc. London 26 (1): 48. 1868.

Figura 4

Plantas com hábito desconhecido. Entrenós incompletos, cilíndricos, 0,8-2,2 cm diâm., verdeamarelados, glabros, opacos; faixa infranodal de tricomas velutinos presente, 1-5,7 mm compr.; lúmen amplo, não preenchido por medula; parede 1,7-3,3 mm de espessura. Nós não proeminentes, castanhos; franja de tricomas na linha nodal ausente. Folhas do colmo não vistas. Complementos de ramo com ca. 50 ramos, 15-33 cm compr., 1,5-2 mm diâm.; ramos de segunda ordem ausentes; nós não proeminentes, castanhos. Folhas dos ramos 4-7 por ramo; bainha 1,5-9,5 cm $\times$ 2-5,3 $\mathrm{mm}$, glabra a pubescente, margem sobreposta ciliada; aurículas ausentes; lígula externa $0,1-0,3 \mathrm{~mm}$ compr.; lígula interna 0,3-1,2 mm compr., pubescente; fímbrias presentes, não fusionadas, 0,7-7,9 mm compr., retas a sinuosas, amareladas a castanhas; pseudopecíolo 1,5-3,9 mm compr., castanho, retorcido, seríceo a híspido; lâmina 4-11,5 × 1,3-2,6 $\mathrm{cm}, \mathrm{C}: \mathrm{L}=2,2-5$, lanceolada a oval lanceolada, face adaxial com 3-4 nervuras marginais escabras, base pubescente, glabro no restante, face abaxial glabra a pubescente, com um tufo de tricomas híspidos na base, ápice escabro, base assimétrica. Inflorescência pectinada, 3,3-9,5 cm compr., 11-38 espiguetas; pedúnculo subtendido pela bainha da última folha do ramo; raque tomentosa, bráctea estéril na base do racemo ausente. Espiguetas 12-17 × 1,5-3 mm, solitárias, 1-flora; pedicelo 1-1,5 mm compr., tomentoso; gluma I 2,5-5 × 1-2 mm, 1-4-nervada, serícea, margem ciliada, aristada, arista $0,5-1,5 \mathrm{~mm}$ compr.; gluma II 12,5-16 × 3,5-5 mm, 12-15-nervada, híspida próximo às nervuras, serícea no restante, margem ciliada apicalmente, ciliada desde a base em um dos lados, aristada, arista 1-1,7 mm compr., ângulo obtuso entre gluma II e raque; lema 12-14 × 4-6,5 mm, 14-19-nervado, opaco, seríceo, margem ciliada apicalmente, ciliada em um dos lados até próximo à base, sem manchas escuras adaxialmente, mútico; pálea 11-14 × 3-5 mm, 6-10-nervada, opaca, pubérula, margem ciliada apicalmente; extensão da ráquila 10,5-13 mm compr. Cariopse não vista.

Material examinado: BRASIL. MinAs GerAis: Viçosa, 13-XII-1934, fl., J.G. Kuhlmann 160 (VIC); sem localidade, 1842, fl., P. Claussen s.n. (Type) (G foto, US).

Na descrição original de Merostachys claussenii, Munro (1868) menciona a presença de 3-4 antécios 


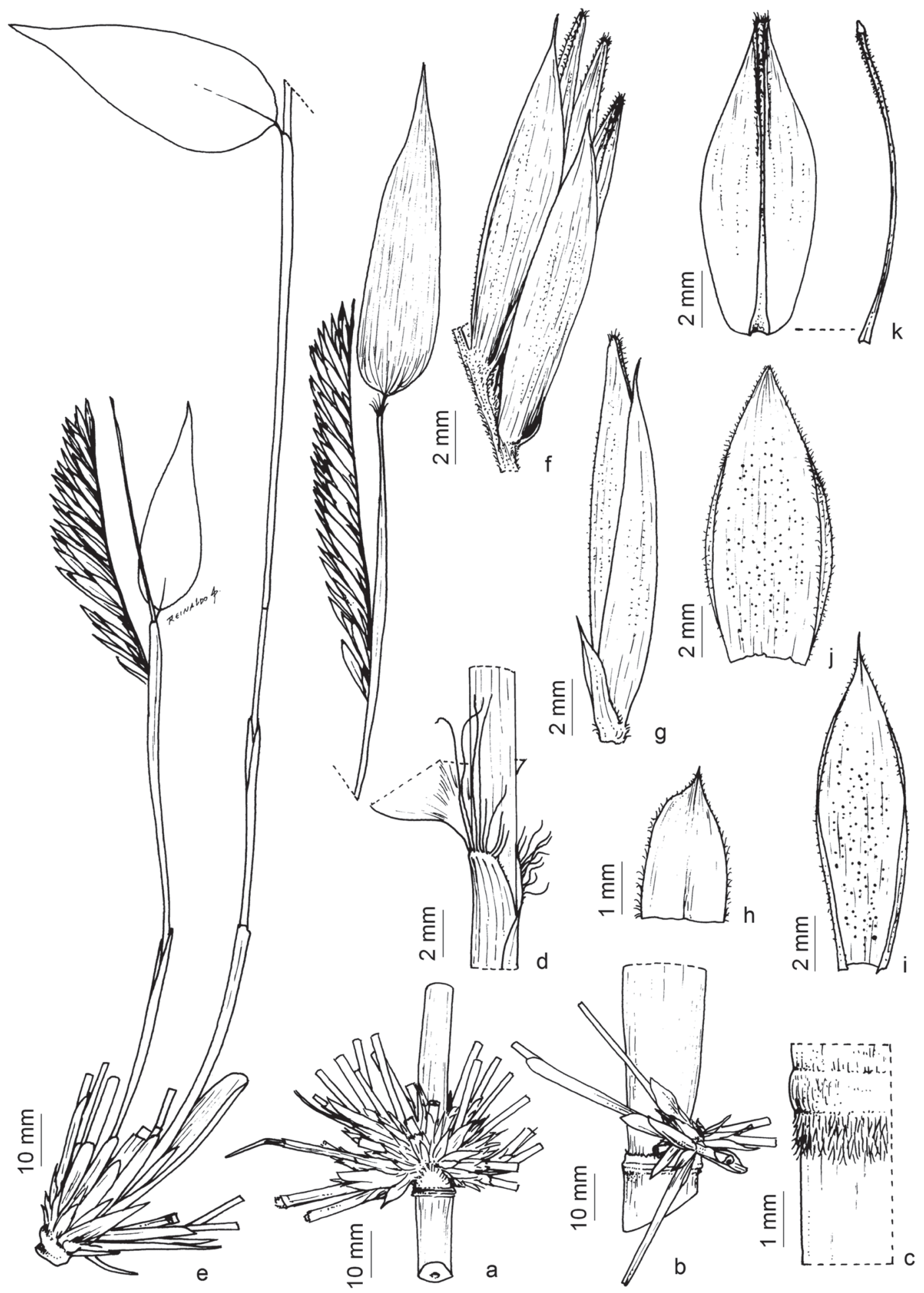

Figura 4. Merostachys claussenii var. claussenii (Kuhlmann 160). a. Complemento de ramo da região apical do colmo. b. Complemento de ramo do mediocolmo. c. Faixa infranodal de tricomas velutinos. d. Região ligular da folha do ramo com fímbrias. e. Ramos floríferos. f. Seção da inflorescência. g. Espigueta. h. Gluma I. i. Gluma II. j. Lema. k. Pálea e extensão da ráquila. (Ilustrado por Reinaldo Pinto).

Figure 4. Merostachys claussenii var. claussenii (Kuhlmann 160). a. Branch complement of the apical region of the culm. b. Branch complement of medium-culm. c. Infranodal band of velutinous trichomes. d. Ligular region of foliage leaf with fimbriae. e. Floriferous branches. f. Section of the inflorescence. g. Spikelet. h. Lower glume. i. Upper glume. j. Lemma. k. Palea and rachilla extension. (Illustrated by Reinaldo Pinto). 
por espigueta; no entanto, a análise do material tipo no herbário US revelou a presença de apenas um antécio. Provavelmente, o autor da espécie considerou cada uma das brácteas estéreis da espigueta como um antécio individual. Em 1880, Döll descreveu $M$. claussenii var. mollior, considerada por McClure (1973) como distinta de M. claussenii var. claussenii devido a características das espiguetas; entretanto, este mesmo autor sugeriu uma reavaliação destes táxons a fim de verificar a necessidade ou não de sinonimização.

Lizarazu et al. (2011) sinonimizaram as duas variedades de $M$. claussenii e $M$. burchellii Munro sob Merostachys claussenii Munro. Entretanto, para propor a referida sinonimização, os materiais tipo das espécies foram analisados apenas por fotos, o que limita a análise dos caracteres; estudos realizados pelo autor sênior nos herbários K e US permitiram verificar diferenças consideráveis nas estruturas reprodutivas entre as duas variedades. Merostachys claussenii var. claussenii possui espiguetas com apenas 1 antécio, gluma II híspida próximo às nervuras e serícea no restante, lema seríceo e bráctea estéril na base do racemo ausente. Merostachys claussenii var. mollior, por sua vez, possui espiguetas com 1-2 antécios, gluma II pubérula a pubescente, lema pubérulo a pubescente $\mathrm{e}$ bráctea estéril na base do racemo geralmente presente.

Devido ao fato de $M$. burchellii ter sido descrita originalmente com base em material vegetativo, serão necessárias novas coletas de material botânico a fim de que se obtenha outros espécimes que permitam acessar a real identidade dessa entidade taxonômica. Diante dessas informações, considera-se, neste estudo, Merostachys claussenii var. claussenii e Merostachys claussenii var. mollior como dois táxons distintos.

Merostachys claussenii var. claussenii aproxima-se de Merostachys aff. riedeliana pelas similaridades no comprimento e largura da espigueta, comprimento e pilosidade das glumas e comprimento do lema e da pálea. Difere, entretanto, pelo comprimento e largura da lâmina das folhas dos ramos, comprimento da inflorescência, número de nervuras da gluma I e comprimento da arista da gluma II.

Dentre os espécimes de Merostachys claussenii var. claussenii examinados, três se encontram depositados na coleção do herbário US (US79092) e foram montados em uma mesma exsicata. Esses espécimes encontram-se posicionados de tal forma que a coleta P. Claussen s.n., composta por duas espiguetas, encontra-se na região inferior da exsicata; a coleta Claussen $51 \mathrm{sem}$ dados de localidade e sem data, composta por um fragmento de bainha da folha do ramo, está afixada na porção mediana da exsicata; por fim, na porção superior da exsicata, está afixado o terceiro espécime, também sem dados de localidade, data e coletor, o qual é composto por um único racemo e uma lâmina da folha do ramo.

Fenologia de floração: o espécime aqui considerado como M. claussenii var. claussenii foi coletado com flor em 1838, 1839, 1854 e 1934; além disso, em um dos espécimes, a etiqueta presente na exsicata informa apenas como data de coleta o intervalo 1838-1842. Esses dados sugerem um ciclo reprodutivo em torno de 20 anos, aproximadamente.

Distribuição: Judziewicz et al. (1999) mencionam que $M$. claussenii var. claussenii está distribuída pelo Leste do Paraguai, Nordeste da Argentina e Sudeste do Brasil. Schimdt \& Longhi-Wagner (2008) mencionaram a ocorrência da espécie, sem especificar qual das duas variedades, para o Rio Grande do Sul. Entretanto, diante das questões taxonômicas supracitadas considera-se, no presente estudo, uma distribuição semelhante àquela citada por Munro (1868) na obra original, com registros para o Rio de Janeiro e Sudeste de Minas Gerais. Os dados relacionados ao hábitat são inexistentes no material examinado.

4. Merostachys claussenii var. mollior J.C. Döll., Fl. Bras. (Martius) 2 (3): 214. 1880. Figura 5

Plantas com hábito desconhecido. Entrenós incompletos, cilíndricos, ca. $1 \mathrm{~cm}$ diâm., verdes com estrias amarelas, minuciosamente escabros, opacos; faixa infranodal de tricomas velutinos presente, ca. 0,4 cm compr.; lúmen amplo, não preenchido por medula; parede ca. $3 \mathrm{~mm}$ de espessura. Nós não proeminentes, castanhos; franja de tricomas na linha nodal ausente. Folhas do colmo não vistas. Complemento de ramo, apenas um visualizado, 41 ramos, 25-35,5 cm compr., ca. 1,8 mm diâm.; ramos de segunda ordem ausentes; nós não proeminentes, castanhos a enegrecidos. Folhas dos ramos 5-7 por ramo; bainha $3,5-7 \mathrm{~cm} \times 2-4 \mathrm{~mm}$, glabra, margem sobreposta não ciliada; aurículas ausentes; lígula externa 0,2-0,3 mm compr.; lígula interna 0,7-1 mm compr., pubescente; fímbrias presentes, não fusionadas, 2-4 $\mathrm{mm}$ compr., retas com ápice levemente sinuoso, a maioria decídua, amareladas; pseudopecíolo 3-4 mm compr., enegrecido, reto a retorcido, pubescente; lâmina depauperada, 


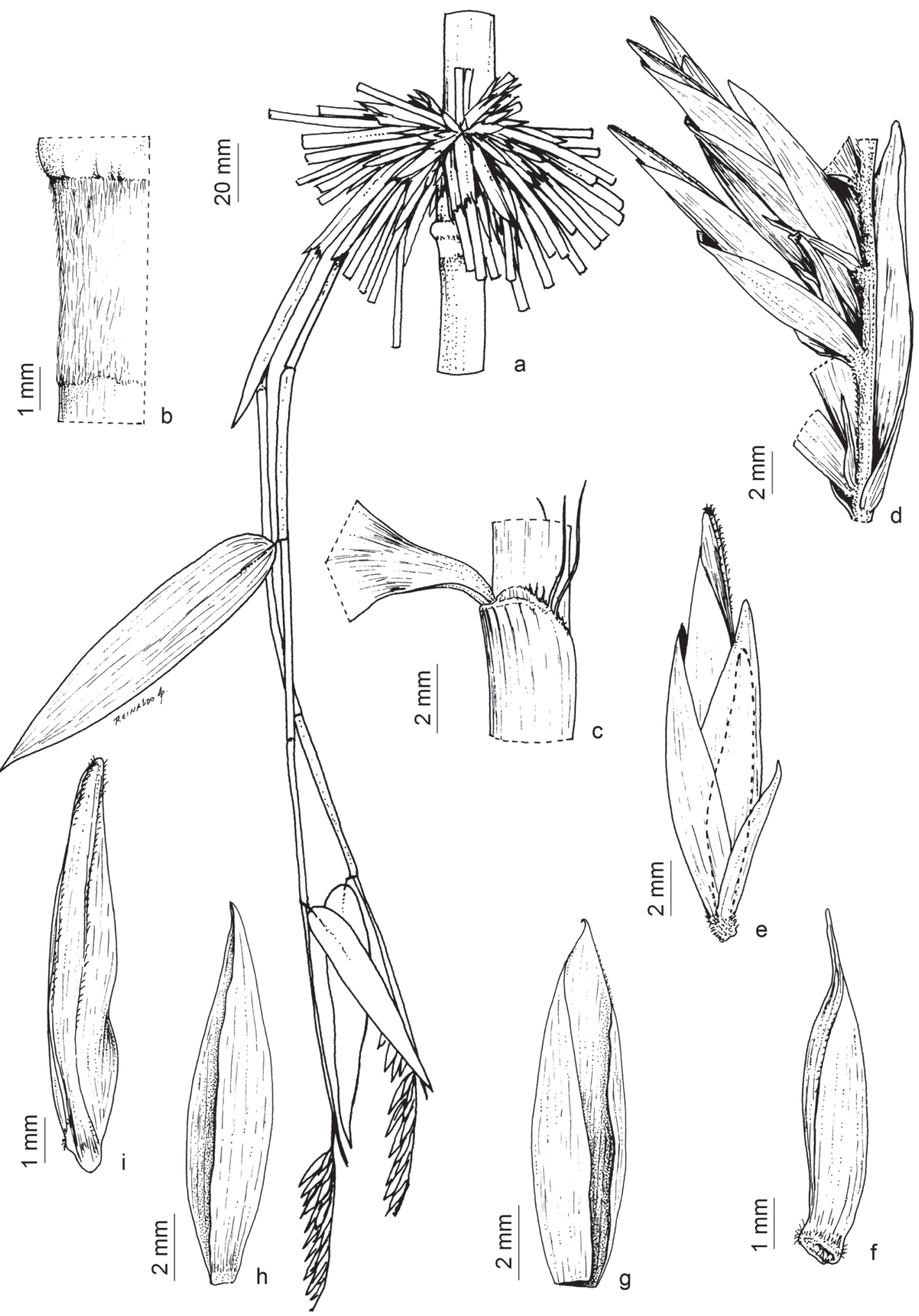

Figura 5. Merostachys claussenii var. mollior (Regnell III 1425). a. Complemento de ramo com folhas e inflorescências. b. Faixa infranodal de tricomas velutinos. c. Região ligular da folha do ramo com fímbrias. d. Seção da inflorescência com bráctea estéril na base. e. Espigueta. f. Gluma I. g. Gluma II. h. Lema. i. Pálea. (Ilustrada por Reinaldo Pinto).

Figure 5. Merostachys claussenii var. mollior (Regnell III 1425). a. Branch complement with leaves and inflorescences. b. Infranodal band of velutinous trichomes. c. Ligular region of foliage leaf with fimbriae. d. Section of the inflorescence with sterile bract at the base. e. Spikelet. f. Lower glume. g. Upper glume. h. Lemma. i. Palea. (Illustrated by Reinaldo Pinto). 
ca. 4,3-7,5 × 1-1,7 cm, lanceolada, face adaxial glabra, face abaxial pubescente na base, glabra no restante, base assimétrica. Inflorescência pectinada, $6,5-7 \mathrm{~cm}$ compr., 23-29 espiguetas; pedúnculo subtendido pela bainha da última folha do ramo; raque tomentosa, base do racemo, por vezes, com uma bráctea estéril 0,7-2,2 cm compr. Espiguetas 10-14 × 2,5-4 mm, solitárias, 1-2-flora; pedicelo $1 \mathrm{~mm}$, tomentoso; gluma I ca. $6,5 \times 2 \mathrm{~mm}, 1-3$-nervada, pubérula a pubescente, margem ciliada apicalmente, em um dos lados ciliada desde a base, aristada, arista ca. 1,5 mm compr.; gluma II ca. $12 \times 5 \mathrm{~mm}, 13$-nervada, pubérula a pubescente, mútica; lema ca. $10 \times 6 \mathrm{~mm}, 12$-nervado, opaco, pubérulo a pubescente, margem ciliada em direção ao ápice, sem manchas escuras adaxialmente, mútico; pálea ca. $10 \times 3 \mathrm{~mm}, 8$-nervada, opaca, pubérula, margem ciliada apicalmente; extensão da ráquila não vista. Cariopse não vista.

Material examinado: BRASIL. MinAs GeraIs: Caldas, 1846, fl., A.F. Regnell III 1425 (Type) (US).

Merostachys claussenii var. mollior é reconhecida pela presença de uma bráctea estéril na base de alguns racemos e pela presença de 1-2 antécios por espigueta. O número de antécios por espigueta a aproxima de $M$. exserta, M. brevigluma e M. riedeliana. No entanto, diferentemente de $M$. claussenii var. mollior, $M$. exserta possui inflorescência com pedúnculo exposto; M. brevigluma possui a gluma II constituindo um ângulo agudo com a raque, e $M$. riedeliana possui espiguetas com comprimento maior do que aquelas apresentadas por Merostachys claussenii var. mollior. Vegetativamente, M. claussenii var. mollior aproxima-se de $M$. skvortzovii pela faixa infranodal de tricomas velutinos e entrenós escabros e verdes com estrias amarelas, e difere da mesma por não apresentar um tufo de tricomas híspidos na base da face abaxial da lâmina das folhas dos ramos.

Lizarazu et al. (2011) sinonimizaram M. burchellii Munro e M. claussenii var. claussenii sob M. claussenii var. mollior, e essa questão já foi discutida nos comentários desta última espécie. Por fim, há que salientar que Sendulsky (1995) considerou M. claussenii var. mollior como sinônimo de M. burchellii Munro emend. Dutra, espécie redescrita por Dutra (1938) a partir de M. burchellii Munro. Essa sinonimização não foi aqui considerada, devido ao fato de que foram observadas algumas diferenças no material reprodutivo como o comprimento da inflorescência e o número de antécios por espigueta. Estudos posteriores podem esclarecer a conveniência de se elevar esse táxon ao nível de espécie.
Fenologia de floração: a espécie foi registrada com flor apenas em 1846, não sendo possível estimar seu ciclo reprodutivo.

Distribuição: Judziewicz et al. (1999) mencionam a ocorrência desta espécie de São Paulo até o Rio Grande do Sul. Em Minas Gerais a espécie foi coletada no município de Caldas, região Sul do Estado. Os dados relacionados ao hábitat são inexistentes no material examinado.

5. Merostachys espessa Vinic.-Silva, L.G. Clark \& Santos-Gonç. Syst. Bot. 41 (4): 961. 2016. Figura 6

Plantas arborescentes com colmos inicialmente eretos e posteriormente inclinando-se sobre a vegetação. Colmos 12-15 m compr. Entrenós 80-120 cm compr., cilíndricos, 1,2-2,2 cm diâm., verdes, escabros, com tricomas seríceos esparsos, glabro nas porções inferior e superior, opacos; faixa infranodal de tricomas ausente; lúmen amplo, às vezes preenchido por medula; parede 2,7-5 $\mathrm{mm}$ de espessura. Nós não proeminentes, castanhos; franja de tricomas na linha nodal presente. Folhas do colmo $15-42,8 \mathrm{~cm}$ compr.; bainha $12-35,5 \times 4,5-8,3 \mathrm{~cm}$; face adaxial glabra, brilhante, face abaxial esparsamente serícea a escabra, margem ciliada no ápice; lígula interna 0,7-2,4 mm compr., membranácea, pubescente, ápice ciliado; fímbrias presentes, não fusionadas, 0,9-5 mm compr., enroladas no ápice, amareladas a castanhas; lâmina 3-7,3 × 0,7-1,4 cm, face adaxial escabra, face abaxial pubérula, margem escabra. Complementos de ramos com 14-55 ramos, 30-56,5 cm compr., 2,5-3 mm diâm.; ramos de segunda ordem presentes; nós não proeminentes, castanhos. Folhas dos ramos 9-11 por ramo; bainha 5-9,7 $\mathrm{cm} \times 6,5-9,5 \mathrm{~mm}$, híspida, margem sobreposta ciliada; aurículas ausentes; lígula externa 0,1-0,4 mm compr.; lígula interna 0,6-1,8 mm compr., pubescente; fímbrias presentes, não fusionadas, 0,6-4,6 mm compr., sinuosas, escassas, esbranquiçadas a castanhas; pseudopecíolo 4,3-11,6 mm compr., castanho, retorcido, pubescente a híspido; lâmina 16-28 × 2-6 cm, C:L = 3,8-6,7, lanceolada a oval lanceolada, face adaxial com 1-3 nervuras marginais escabras, margem oposta e ápice com diminutos tricomas estrigosos, glabra no restante, face abaxial com uma faixa de diminutos tricomas estrigosos em direção ao ápice, próxima à estria discolor, glabra no restante, tufo de tricomas híspidos na base ausente, base assimétrica. Inflorescência não vista. 


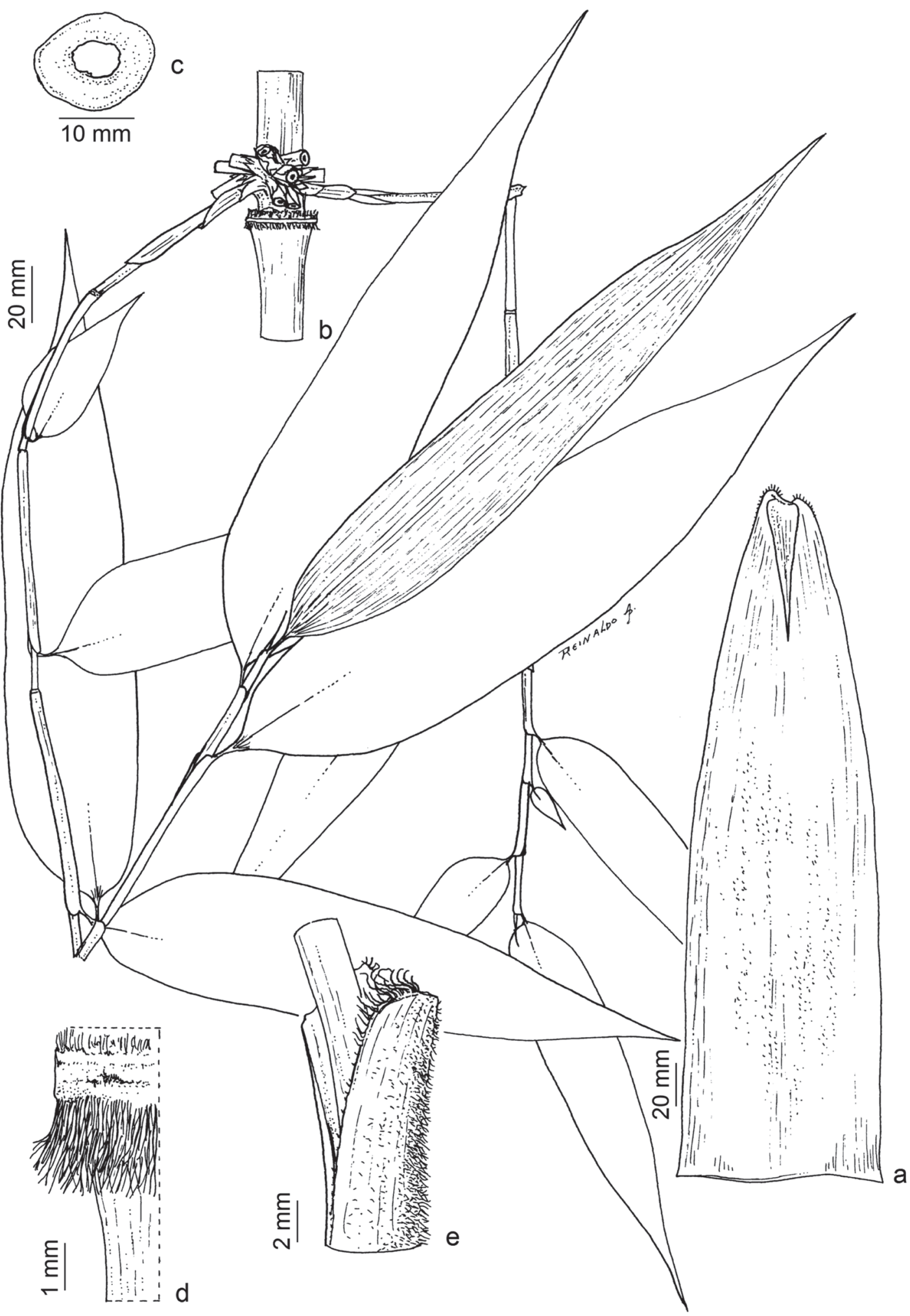

Figura 6. Merostachys espessa (R.V. Silva et al. 32). a. Folha do colmo. b. Complemento de ramo com folhas. c. Seção transversal do colmo. d. Franja de tricomas na linha nodal. e. Região ligular da folha do ramo e fímbrias. (Ilustrada por Reinaldo Pinto).

Figure 6. Merostachys espessa (R.V. Silva et al. 32). a. Culm leaf. b. Branch complement with leaves. c. Cross section of the culm. d. Fringe of trichomes on the nodal line. e. Ligular region of foliage leaf with fimbriae. (Illustrated by Reinaldo Pinto). 
Material examinado: BRASIL. Minas Gerais: Santa Maria do Salto, Parque Estadual do Alto Cariri, Região do Fró, 15-V-2014, veg., R.V. Silva, J.I. Silva, A. Souza \& D.P. Santos 32 (Type) (ISC, MO, SP, VIC).

Merostachys espessa distingue-se das demais espécies do gênero por apresentar entrenós com parede espessa, inclusive na região mediana do colmo, e lúmen estreito. Por vezes, os entrenós do mediocolmo são preenchidos por medula.

Fenologia de floração: a espécie foi registrada, até o momento, somente em estádio vegetativo.

Distribuição: a espécie ocorre na região Nordeste de Minas Gerais, no Parque Estadual Alto Cariri (Vinícius-Silva et al. 2016), onde pode ser encontrada em sub-bosque de vegetação caracterizada por Veloso et al. (1991) como Floresta Atlântica Estacional Semidecidual Montana.

6. Merostachys exserta Munro ex Camus, Les Bambusées 74. 1913.

\section{Figura 7}

Plantas arborescentes com colmos inicialmente eretos e posteriormente inclinando-se sobre a vegetação. Colmos 5-8 m compr. Entrenós com 20-57 cm compr., cilíndricos, 0,8-2,4 cm diâm., verde-amarelados, glabros a escabros, opacos; faixa infranodal de tricomas velutinos presente, 2,5-5,8 mm compr.; lúmen amplo, não preenchido por medula; parede 1,5-2,5 $\mathrm{mm}$ de espessura. Nós não proeminentes, castanhos a enegrecidos; franja de tricomas na linha nodal ausente. Folhas do colmo não vistas. Complementos de ramos com 50-497 ramos, 12-49 cm compr., 0,7-1,2 mm diâm.; ramos de segunda ordem ausentes; nós não proeminentes, castanhos a enegrecidos. Folhas dos ramos 4-12 por ramo; bainha 1-4,2 $\mathrm{cm} \times 1,2-2,2 \mathrm{~mm}$, glabra a pubescente, às vezes hirsuta ou tomentosa próximo à margem sobreposta, margem sobreposta ciliada; aurículas ausentes; lígula externa $0,05-0,1 \mathrm{~mm}$ compr.; lígula interna 0,1-0,4 mm compr., pubescente; fímbrias presentes, não fusionadas, 0,2-9,5 $\mathrm{mm}$ compr., retas a sinuosas, às vezes enroladas no ápice, amareladas a avermelhadas; pseudopecíolo 0,9-3,2 mm compr., esverdeado a castanho, retorcido, glabro a pubescente; lâmina 4-9,5 × 0,3-1 cm, C:L= 5,6-12, lanceolada, face adaxial com 2-4 nervuras marginais escabras, ápice escabro, glabra no restante, face abaxial glabra a hirsuta, ápice escabro, base simétrica. Inflorescência pectinada, 1,3-4,7 cm compr., 9-31 espiguetas; pedúnculo exposto; raque velutina, bráctea estéril na base do racemo ausente. Espiguetas 6-8 $\times 1-1,5 \mathrm{~mm}$, solitárias, 1-2-flora; pedicelo $0,3-0,8 \mathrm{~cm}$, tomentoso; gluma I 0,7-1,8 × 0,3-1 mm, 1-nervada, glabra a pubescente, margem ciliada no ápice, mútica; gluma II 3-5 × 1,5-3 mm, 5-9-nervada, glabra a pubescente, às vezes pubérula, margem ciliada no ápice, mucronada, ângulo obtuso entre gluma II e raque; lema 4-6,7 × 2,5-4 mm, 8-12-nervado, opaco, pubescente a esparsamente seríceo, margem ciliada em direção ao ápice, com manchas escuras adaxialmente, mútico; pálea 5-7 × 2,5-3 mm, 6-8-nervada, opaca, pubescente em direção ao ápice, margem ciliada no ápice; extensão da ráquila 3-5,5 $\mathrm{mm}$ compr. Cariopse 3-4,7 × 1-1,3 mm, elipsóide, rostrada, castanha, hilo conspícuo.

Material examinado: BRASIL. Minas Gerais: Simonésia, RPPN Mata do Sossego, 20-III-2009, fl., J.R. Stehmann, I.C. Campos, J.C. Braidotti, A.L.M. Assis \& N.G. Oliveira 6048 (BHCB); idem, Trilha da BR, ponto 6, 20-XI-2014, veg., R.V. Silva \& J.J. Andrade 55 (VIC); Ouro Preto, Parque Estadual do Itacolomi, Morro do Cachorro, subida da Fazenda do Manso para as Antenas, 11-XI-2009, fl., E.S. Cândido, J.L. Silva \& M.O. Bünger 252 (OUPR); sem localidade, 1816 a 1821, Auguste de Saint-Hilaire Cat. D. 713 (Type) (P foto, US).

Merostachys exserta aproxima-se de $M$. fischeriana pelas medidas de comprimento e na largura da espigueta e de suas brácteas constituintes, além da presença, nas duas espécies, de uma faixa infranodal de tricomas velutinos. Difere, entretanto, por características de pilosidade do entrenó, número de antécios por espigueta e pilosidade do lema. Merostachys exserta também assemelha-se a Merostachys leptophylla por apresentar a superficie abaxial da lâmina das folhas dos ramos completamente glabra; no entanto, difere pelo comprimento da espigueta, pilosidade do lema, quantidade de ramos no complemento de ramo, espessura da parede do entrenó e presença de uma faixa infranodal de tricomas. Por fim, essa espécie também possui semelhanças com $M$. claussenii var. mollior, as quais já foram discutidas nos comentários dessa espécie.

Fenologia de floração: a espécie foi coletada em estádio reprodutivo em 1816, 1821,1914, 1928, 1978 e 2009, não sendo possível estimar seu ciclo reprodutivo.

Distribuição: Merostachys exserta é registrada, até o momento, apenas para o Sudeste do Estado 


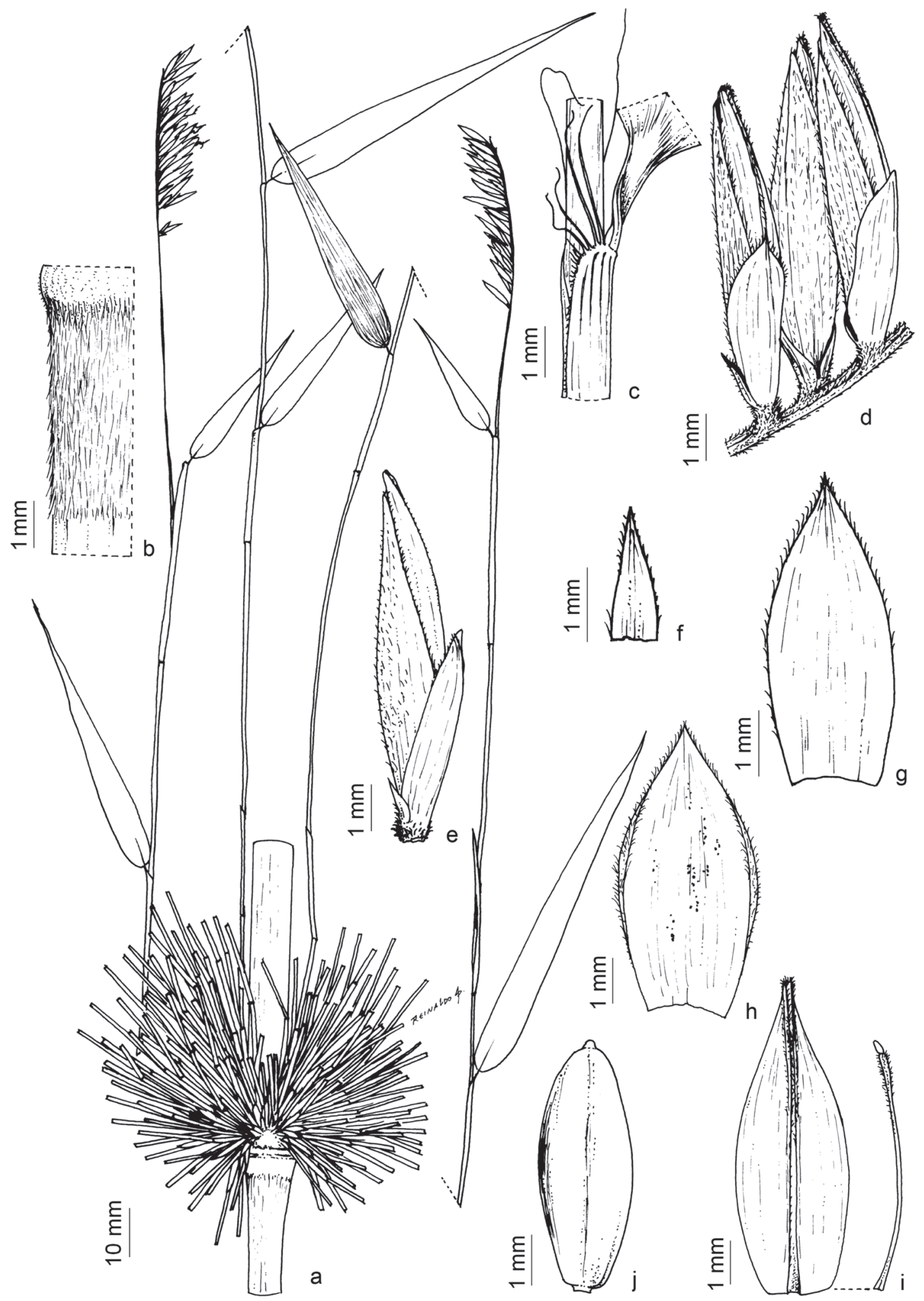

Figura 7. Merostachys exserta (Stehmann et al. 6048). a. Complemento de ramo com folhas. b. Faixa infranodal de tricomas velutinos. c. Região ligular da folha do ramo e fímbrias. d. Seção da inflorescência. e. Espigueta. f. Gluma I. g. Gluma II. h. Lema. i. Pálea e extensão da ráquila. j. Cariopse. (Ilustrada por Reinaldo Pinto).

Figure 7. Merostachys exserta (Stehmann et al. 6048). a. Branch complement with leaves. b. Infranodal band of velutinous trichomes. c. Ligular region of foliage leaf and fimbriae. d. Section of the inflorescence. e. Spikelet. f. Lower glume. g. Upper glume. h. Lemma. i. Palea and rachilla extension. j. Caryopsis. (Illustrated by Reinaldo Pinto). 
de Minas Gerais (Judziewicz et al. 1999), em subbosque e borda de vegetação caracterizada por Veloso et al. (1991) como Floresta Atlântica Estacional Semidecidual Montana.

7. Merostachys fimbriolaminata Vinic.-Silva, Cup.Eisenlohr \& Santos-Gonç. Syst. Bot. 41 (4): 961. 2016.

Figura 8

Plantas arborescentes com colmos inicialmente eretos, arqueando-se no ápice. Colmos 18-20 m compr. Entrenós 50-116 cm compr., cilíndricos, 2,4-2,7 cm diâm., verde-amarelados a verde-acinzentados, glabros, opacos; faixa infranodal de tricomas lanosos presente, 0,5-1 cm compr.; lúmen amplo; parede 1,3-2,5 $\mathrm{mm}$ de espessura. Nós proeminentes, castanho-escuros; franja de tricomas na linha nodal ausente. Folhas do colmo 25,2-53,5 cm compr; bainha $18,7-36 \times 8,8-10,8 \mathrm{~cm}$, face adaxial glabra, brilhante, face abaxial glabra a pubescente, margem ciliada no ápice; lígula interna 1-2 mm compr., membranácea, pubescente, ápice ciliado; fímbrias presentes, fusionadas na base em direção ao ápice, formando uma estrutura cuneiforme de aparência laminar, 7,4-20,4 mm compr., amareladas a castanhas; fímbrias individuais às vezes se desprendendo do corpo da estrutura; lâmina 6,5-17,5 × 1-2 cm, pubescente em ambas as faces, margem escabra. Complementos de ramos com 7-86 ramos, 40-82 cm compr., 2,9-4,5 mm diâm.; ramos de segunda ordem ausentes; nós proeminentes, castanho-escuros. Folhas dos ramos 5-16 por ramo; bainha 4-14,5 $\mathrm{cm} \times 6-11 \mathrm{~mm}$, glabra a pubérula, às vezes hirsuta, margem sobreposta ciliada; aurículas ausentes; lígula externa $0,2-0,4 \mathrm{~mm}$ compr.; lígula interna $0,7-1,8 \mathrm{~mm}$ compr., pubescente; fímbrias presentes, fusionadas na base em direção ao ápice, formando uma estrutura cuneiforme de aparência laminar, 1,2-3,9 mm compr., amareladas a castanhas; fimbrias individuais às vezes se desprendendo do corpo da estrutura; pseudopecíolo 5-10,5 mm compr., castanho, retorcido, glabro a pubescente; lâmina 13,5-32,5 × 2,7-8,3 cm, C:L = 3-7, lanceolada a oval lanceolada, face adaxial glabra, ápice escabro, face abaxial com uma faixa de diminutos tricomas estrigosos em direção ao ápice, próxima à estria discolor, glabra no restante, tufo de tricomas híspidos na base ausente, base assimétrica. Inflorescência não vista.

Material examinado: BRASIL. MinAs Gerais: Santa Maria do Salto, Parque Estadual Alto Cariri, Córrego do Belém, Floresta da Pimenteira, 13-V-2014, veg., R.V. Silva \& J.I. Silva 24 (Type) (ISC, MO, SP, VIC); Fazenda Limeira, 14-V-2014, veg., R.V. Silva et al. 28 (Type) (VIC); Almenara, Fazenda Limoeiro, 28-II-2004, J.A. Lombardi et al. 5663 (Type) (BHCB).

Merostachys fimbriolaminata assemelha-se a M. speciosa Spreng. pela ocorrência de fimbrias basalmente fusionadas; no entanto, distingue-se pelo fato de as fímbrias constituírem uma estrutura cuneiforme de aspecto laminar, e por apresentar os nós do colmo e dos ramos espessados, castanho-escuros. Merostachys fimbriolaminata também aproxima-se de $M$. annulifera Send. e M. ximenae pela presença de nós espessados no colmo e nos ramos; no entanto, difere por apresentar fímbrias fusionadas na base em direção ao ápice.

Fenologia de floração: a espécie foi registrada, até o momento, somente em estádio vegetativo.

Distribuição: a espécie é registrada para a região Nordeste de Minas Gerais (Vinícius-Silva et al. 2016), onde pode ser encontrada em borda de vegetação caracterizada por Veloso et al. (1991) como Floresta Atlântica Estacional Semidecidual Montana.

\section{Merostachys fischeriana Rupr. ex Döll, Fl. Bras. 2} (3): 215.1880.

\section{Figura 9}

Plantas arborescentes com colmos inicialmente eretos e posteriormente inclinando-se sobre a vegetação. Colmos 8-12 m compr. Entrenós 8-65 cm compr., cilíndricos, 0,3-2 cm diâm., verde-amarelados, glabros, lustrosos; faixa infranodal de tricomas velutinos presente, 1-6 mm compr.; região de coloração verde-escuro abaixo da faixa infranodal de tricomas; lúmen amplo, não preenchido por medula; parede 1-4,5 mm de espessura. Nós não proeminentes, castanhos a enegrecidos; franja de tricomas na linha nodal ausente. Folhas do colmo 25,5-46 cm compr.; bainha 13,5-32 × 2,6-10,5 cm, face adaxial glabra, brilhante, face abaxial com base pubescente a serícea, glabra no restante, às vezes escabra ou hirsuta em direção ao ápice, margem sobreposta ciliada no ápice; lígula interna 0,3-1,4 mm compr., membranácea, pubescente, ápice ciliado; fímbrias presentes, não fusionadas, 1,3-11,3 mm compr., retas a sinuosas, enroladas no ápice, amareladas a avermelhadas; lâmina 1,2-1,4 × 0,1-0,2 cm, face adaxial escabra, face abaxial glabra a minuciosamente escabra, às vezes esparsamente hirsuta, margem 


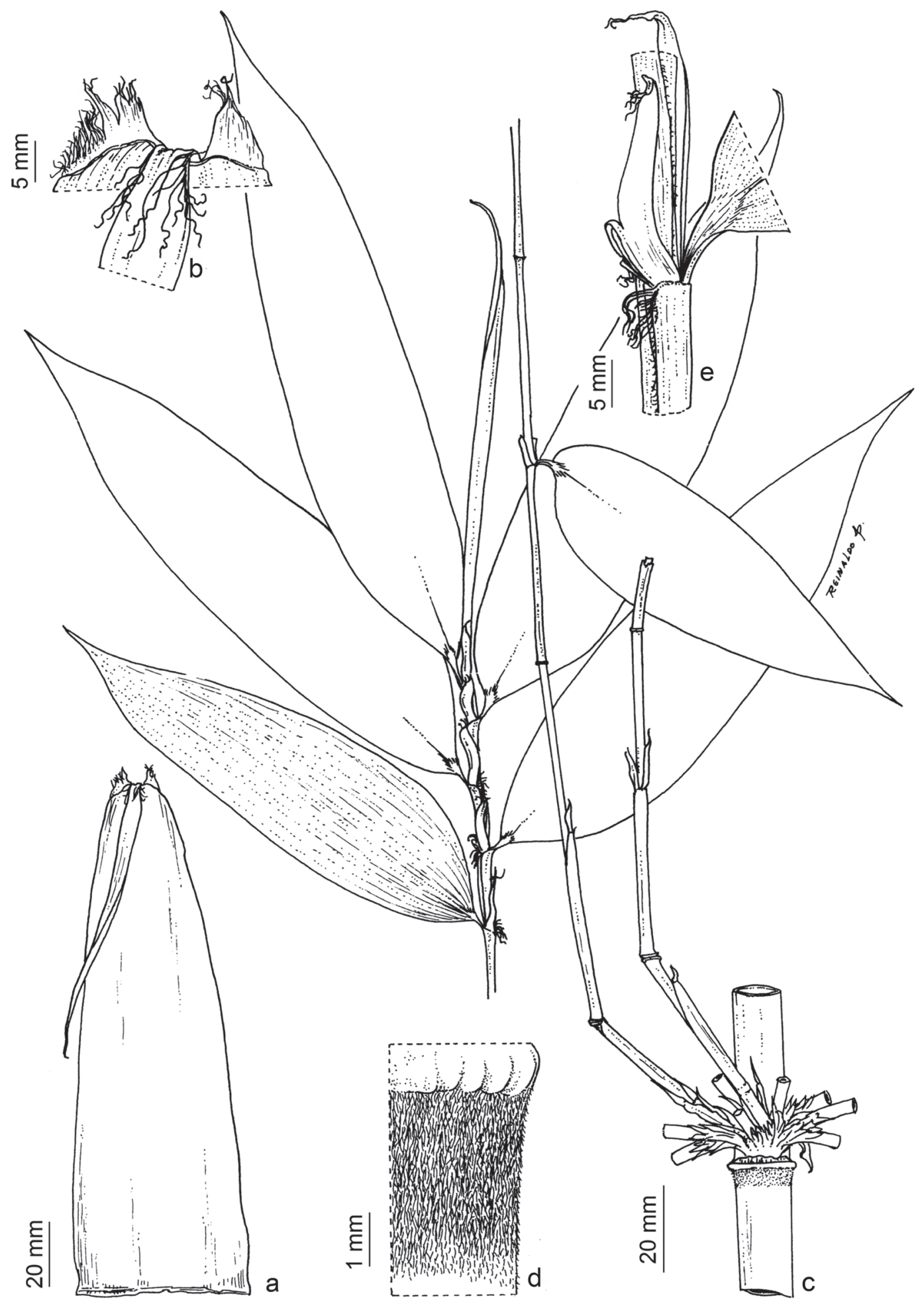

Figura 8. Merostachys fimbriolaminata (R.V. Silva \& J.I. Silva 24). a. Folha do colmo. b. Ápice da folha do colmo com fímbrias fusionadas. c. Complemento de ramo com folhas. d. Faixa infranodal de tricomas velutinos. e. Região ligular com folha do ramo e fímbrias fusionadas. (Ilustrada por Reinaldo Pinto).

Figure 8. Merostachys fimbriolaminata (R.V. Silva \& J.I. Silva 24). a. Culm leaf. b. Apex of culm leaf with fused fimbriae. c. Branch complement with leaves. d. Infranodal band of velutinous trichomes. e. Ligular region with foliage leaf and fused fimbriae. (Illustrated by Reinaldo Pinto). 


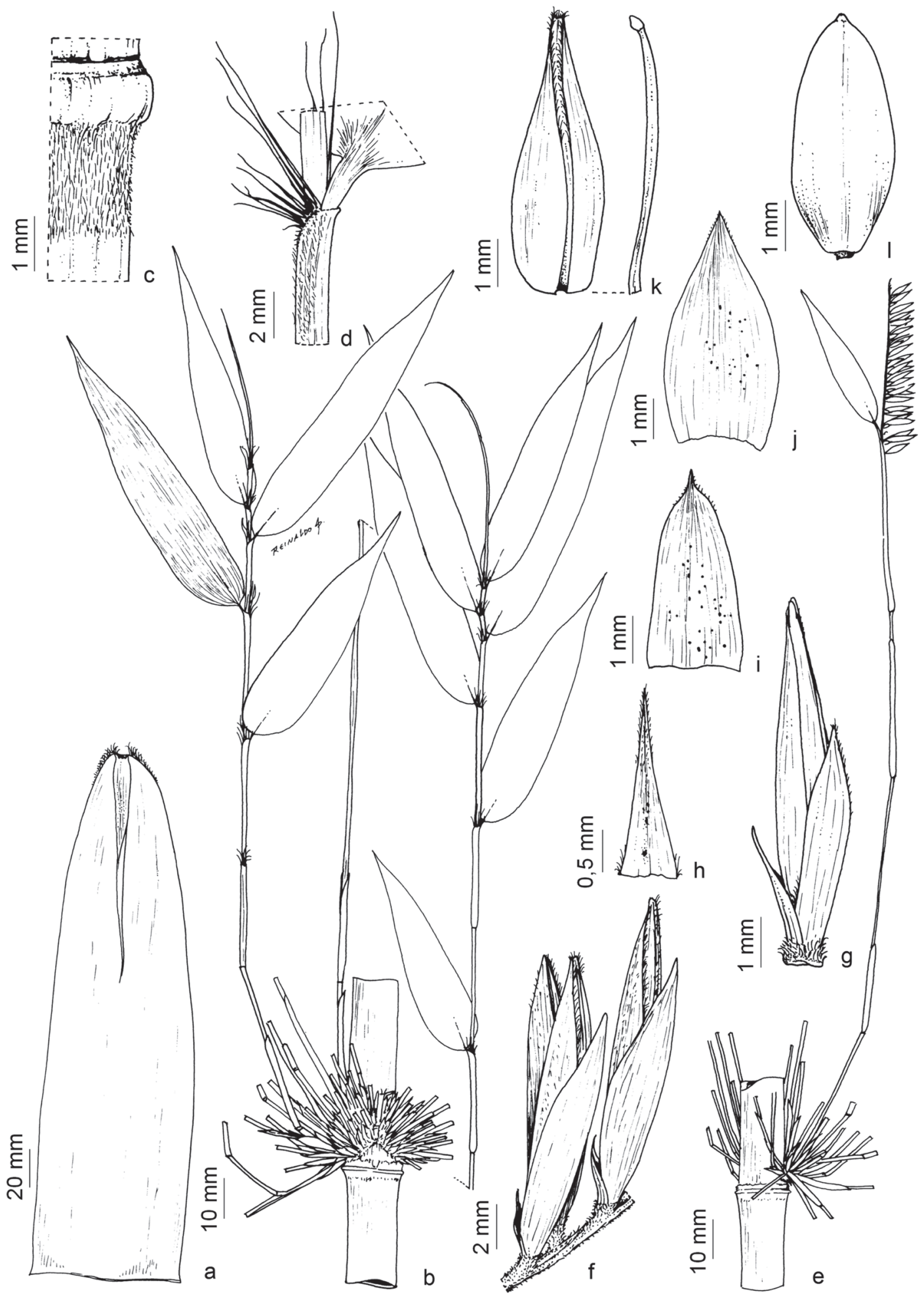

Figura 9. Merostachys fischeriana (Ferreira et al.1092). a. Folha do colmo. b. Complemento de ramo com ramos floríferos. c. Faixa infranodal de tricomas velutinos. d. Região ligular da folha do ramo com fímbrias. e. Complemento de ramo com ramos vegetativos. f. Seção da inflorescência. g. Espigueta. h. Gluma I. i. Gluma II. j. Lema. k. Pálea e extensão da ráquila. 1. Cariopse. (Ilustrada por Reinaldo Pinto).

Figure 9. Merostachys fischeriana (Ferreira et al. 1092). a. Culm leaf. b. Branch complement with floriferous branches. c. Infranodal band of velutinous trichomes. d. Ligular region of foliage leaf with fimbriae. e. Branch complement with vegetative branches. f. Section of the inflorescence. g. Spikelet. h. Lower glume. i. Upper glume. j. Lemma. k. Palea and rachilla extension. 1. Caryopsis. (Illustrated by Reinaldo Pinto). 
escabra. Complementos de ramos com 30-168 ramos, 13-77,5 cm compr., 0,9-1,7 mm diâm.; ramos de segunda ordem ausentes; nós não proeminentes, castanhos a enegrecidos. Folhas dos ramos 4-17 por ramo; bainha 1,3-9 $\mathrm{cm} \times 1,3-4,4 \mathrm{~mm}$, pubescente a tomentosa, às vezes glabra ou hirsuta, margem sobreposta ciliada; aurículas ausentes; lígula externa 0,1-0,3 mm compr.; lígula interna 0,1-0,6 mm compr., pubescente; fímbrias presentes, não fusionadas, 1-21,6 mm compr., retas a sinuosas, por vezes enroladas no ápice, amareladas a avermelhadas; pseudopecíolo 1,2-4,6 mm compr., esverdeado a castanho, retorcido, pubescente a tomentoso; lâmina 5-14,7 × 0,7-2,6 cm, C:L = 4,6-10,4, lanceolada, face adaxial com 2-4 nervuras marginais escabras, região marginal oposta com diminutos tricomas estrigosos antrorsos em direção ao ápice, glabra no restante, face abaxial glabra a pubescente, ás vezes hirsuta, faixa de diminutos tricomas estrigosos antrorsos em direção ao ápice, próxima à estria discolor, tufo de tricomas híspidos na base às vezes presente, base simétrica a assimétrica. Inflorescência pectinada, 3-7,7 cm compr., 23-55 espiguetas; pedúnculo às vezes exposto; raque velutina, bráctea estéril na base do racemo ausente. Espiguetas 6-9 × 1-3 mm, solitárias, 1-flora; pedicelo 0,5-1 mm compr., velutino a tomentoso; gluma I 1-2,8 $\times$ 0,3-1 mm, 1-nervada, glabra a pubescente, margem ciliada, mútica; gluma II 3-6 × 1,5-2,5 mm, 5-10-nervada, glabra a pubescente, margem ciliada apicalmente, mucronada, ângulo obtuso entre gluma II e raque; lema 5-8 × 2,5-4 mm, 9-13-nervado, opaco, glabro a pubescente, margem ciliada apicalmente, com manchas escuras adaxialmente, mútico; pálea 5-8,3 $\times 2$-4 mm, 6-9-nervada, opaca, glabra a pubescente no ápice, margem ciliada no ápice; extensão da ráquila $3,5-7,5 \mathrm{~mm}$ compr. Cariopse 0,3-0,5 $\times 0,1-0,3 \mathrm{~mm}$, oval, rostrada, castanha, hilo conspícuo.

Material selecionado: BRASIL. MinAs Gerais: Brás Pires, Rodovia Senador Firmino-Brás Pires, MG-124, 9-III-2014, veg., R.V. Silva \& E.A. Silva 12 (VIC); Carrancas, Serra dos Perdizes, 2-XII-2007, fl., P.L. Viana, F.S.F. Leite \& C.G. Leal 3325 (BHCB); Catas Altas, Reserva Particular do Patrimônio Natural Santuário do Caraça, 11-VI-2000, veg., R. C. Mota 837 (BHCB); Conceição do Mato Dentro, Parque Estadual Serra do Intendente, Capão do Felipe, 25-VIII-2006, fl., fr., P.L. Viana, F.S.F. Leite, C.G. Leal, G. do Rai \& N.F.O. Mota 2845 (BHCB); Gonzaga, Fazenda do Sr. Gezier Nunes, 5-IX-2008, veg., L.H.Y. Kamino
\& L. Maielo-Silva 1174 (BHCB); Jaboticatubas, Km 126 ao longo da rodovia Lagoa Santa - Conceição do Mato Dentro - Diamantina, 7-IV-1974, fl., J. Semir \& M. Sazima 4977 (UEC); Lima Duarte, Conceição do Ibitipoca, Parque Estadual do Ibitipoca, 16-III-2005, fl., R. Dias-Melo, R.D. Ribeiro, R. Marquette, E. Von S. Medeiros \& J.R. Fernandes 222 (RB); Rio Vermelho, Serra do Ambrósio, 1-X-2006, fl., fr., P.L. Viana, F.S.F. Leite, L.E. Lopes \& M. Ferreira 2408 (BHCB); Santa Luzia, XI-1834, fl., Riedel 2986 (Type) (G foto, K, US); São Gonçalo, EPDA-PETI, 15-XII-1994, fl., M. Passamani s.n. (VIC); Viçosa, 6-XI-1930, fl., I. Mexias 4578 (VIC); Fazenda Bom Sucesso, Mata do Sr. Nico, 12-IX-2014, veg., D.F. Parma \& Celso Antônio 48 (VIC).

Merostachys fischeriana aproxima-se de $M$. exserta, e suas semelhanças e diferenças foram discutidas nos comentários desta espécie. Merostachys fischeriana assemelha-se ainda a Merostachys aff. fischeriana pela presença de uma faixa infranodal de tricomas velutinos, pela pilosidade do entrenó e pelo comprimento da espigueta; distingue-se, no entanto, pela pilosidade do lema e por apresentar manchas escuras abaxialmente nesta mesma bráctea.

Fenologia de floração: Merostachys fischeriana foi coletada em estádio reprodutivo em 1834, 1930, 1974, 2005, 2006, 2007 e 2014, o que sugere um ciclo reprodutivo de 45 anos.

Distribuição: a espécie é registrada para Minas Gerais (Judziewicz et al. 1999), Bahia e Rio de Janeiro por Renvoize (1984); no entanto, para o Estado do Rio de Janeiro não foi localizado, até o momento, nenhum material testemunho para análise. $\mathrm{Na}$ área de estudo a espécie é amplamente distribuída, ocorrendo nas regiões Sul, Sudeste, Leste e Central de Minas Gerais, em sub-bosque e borda de vegetação caracterizada por Veloso et al. (1991) como Floresta Atlântica Estacional Semidecidual Montana.

9. Merostachys fistulosa Döll, Fl. Bras. 2 (3): 209, pl. 55. 1880.

Figura 10

Plantas arborescentes com colmos inicialmente eretos e posteriormente inclinando-se sobre a vegetação. Colmos 10-15 m compr. Entrenós 5-63 cm compr., cilíndricos, 0,6-2,5 cm diâm., verde com estrias amarelas, escabros, pubescentes a seríceos próximo aos nós, opacos; faixa infranodal de tricomas ausente; lúmen amplo, não preenchido 


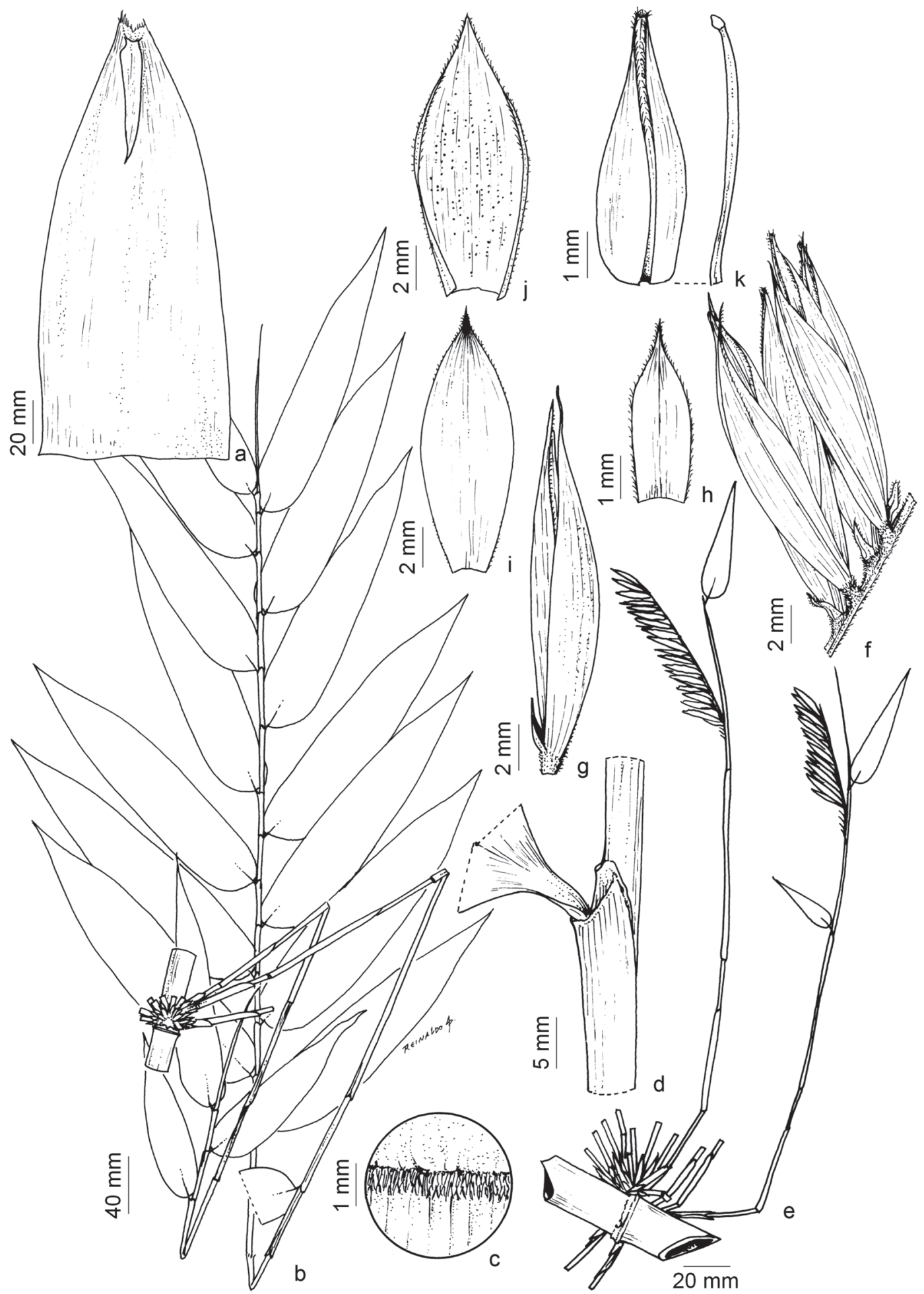

Figura 10. Merostachys fistulosa. a-d. (R.V. Silva et al. 50). e-k. (Vieira 1356). a. Folha do colmo. b. Complemento de ramo com ramos vegetativos. c. Franja de tricomas na linha nodal. d. Região ligular da folha do ramo sem fímbrias. e. Complemento de ramo com ramos floríferos. f. Seção da inflorescência. g. Espigueta. h. Gluma I. i. Gluma II. j. Lema. k. Pálea e extensão da ráquila. (Ilustrada por Reinaldo Pinto).

Figure 10. Merostachys fistulosa. a-d. (R.V. Silva et al. 50). e-k. (Vieira 1356). a. Culm leaf. b. Branch complement with vegetative branches. c. Fringe of trichomes in the nodal line. d. Ligular region of the foliage leaf without fimbriae. e. Branch complement with floriferous branches. f. Section of the inflorescence. g. Spikelet. h. Lower glume. i. Upper glume. j. Lemma. k. Palea and rachilla extension. (Illustrated by Reinaldo Pinto). 
por medula; parede com 1-3 mm de espessura. Nós não proeminentes, castanhos; franja de tricomas na linha nodal presente. Folhas do colmo $11-47 \mathrm{~cm}$ compr.; bainha 9-40 × 3-12,7 cm, face adaxial glabra, brilhante, face abaxial pubescente a esparsamente serícea, frequentemente escabra, margem ciliada no ápice, margem sobreposta ciliada desde a base; lígula interna 0,4-13 mm compr., membranácea, pubérula a pubescente; fímbrias ausentes; lâmina 1,8-7 $\times 0,4-1 \mathrm{~cm}$, face adaxial glabra a pubescente, ápice escabro, face abaxial glabra a pubescente, ápice escabro, margem escabra. Complementos de ramos 6-74 ramos, 24,5-155 cm compr., 2,3-4,9 $\mathrm{mm}$ de diâm.; ramos de segunda ordem ausentes; nós não proeminentes, castanhos a enegrecidos. Folhas dos ramos 6-33 por ramo; bainha 2-18 $\mathrm{cm} \times 1,7-15,6 \mathrm{~mm}$, glabra a pubescente, às vezes hirsuta ou escabra, margem sobreposta ciliada; aurículas ausentes; lígula externa 0,2-0,8 mm compr.; lígula interna 1-10 mm compr., pubérula; fímbrias ausentes; pseudopecíolo 2-9,6 mm compr., esverdeado a castanho, retorcido, glabro a pubescente; lâmina 5,5-27 × 0,7-8 cm, $C: L=3-7,5$, lanceolada a oval lanceolada, face adaxial com 1-3 nervuras marginais escabras, ápice escabro, glabra no restante, face abaxial com uma faixa de diminutos tricomas estrigosos antrorsos em direção ao ápice, próxima à estria discolor, glabra no restante, base simétrica a assimétrica. Inflorescência pectinada, 4,5-14 cm compr., 18-46 espiguetas; pedúnculo subtendido pela bainha da última folha do ramo; raque tomentosa, bráctea estéril na base do racemo ausente. Espiguetas 17-20 × 2-3 mm, solitárias, 1-flora; pedicelo $1 \mathrm{~mm}$ compr., tomentoso; gluma I 3-6 × 1-1,5 mm, 1-nervada, serícea, margem ciliada, aristada, arista 0,5-1,5 mm compr.; gluma II $16-20 \times 5 \mathrm{~mm}, 10-12$-nervada, híspida próximo à nervura central, serícea no restante, margem ciliada no ápice, em um dos lados ciliada desde a base, aristada, arista 1-3 mm compr., por vezes ultrapassando a extensão do antécio, ângulo obtuso entre gluma II e raque; lema 15-17 × 6-8 mm, 15-18-nervado, opaco, pubescente a seríceo, ápice com uma franja de tricomas, sem manchas escuras adaxialmente, aristado, arista 2-3 mm compr.; pálea 12,5-18 × 4,5-5 mm, 8-10-nervada, opaca, pubérula a pubescente, margem ciliada no ápice; extensão da ráquila $12-13 \mathrm{~mm}$ compr. Cariopse não vista.

Material examinado: BRASIL. Minas Gerais: Caldas, 28-XII-1859, fl., A.F. Regnell II 1424 (Type) (US); Monte Belo, RPPN Fazenda Lagoa, Mato Olaria,
Trilha 9, 9-XI-1987, fl., M.C.W. Vieira 1356 (RB); idem, São Francisco, Mata da Olaria, 6-XI-2014, veg., R.V.Silva, C.G. Coelho, S.H. Freitas, M.V.M. Marques \& M.C.W. Vieira 50 (VIC); Ibirité, Parque Estadual da Serra do Rola Moça, Estrada para o Manancial Rola Moça, 23-VII-2014, veg., R.V. Silva et al. 42 (VIC).

Merostachys fistulosa pode ser reconhecida vegetativamente pela ausência de fímbrias tanto nas folhas do colmo como nas folhas dos ramos.

Fenologia de floração: a espécie foi coletada em floração nos anos de 1854, 1987 e 2015, o que sugere um ciclo reprodutivo de, aproximadamente, 30 anos.

Distribuição: Merostachys fistulosa ocorre em Minas Gerais (Judziewicz et al. 1999) e São Paulo (Flora do Brasil 2020). No Estado de Minas Gerais distribui-se pelas regiões Sul, Sudeste e Central, onde é encontrada em sub-bosque e borda de vegetação caracterizada por Veloso et al. (1991) como Floresta Atlântica Estacional Semidecidual Montana.

10. Merostachys leptophylla Send., Novon 3 (7): 295. 1997.

Figura 11

Plantas escandentes. Colmos 2-5,3 m compr. Entrenós 5,3-43,2 cm compr., cilíndricos, 0,3-0,6 cm diâm., verde-amarelados, glabros, geralmente cobertos por uma camada de cera branca, lustrosos; faixa infranodal de tricomas ausente; lúmen amplo, não preenchido por medula; parede $0,5-1 \mathrm{~mm}$ de espessura. Nós não proeminentes, castanhos; franja de tricomas na linha nodal ausente. Folhas do colmo 7,6-26 cm compr.; bainha 4,4-12,2 × 0,5-3 cm; face adaxial glabra, brilhante, face abaxial glabra, margem ciliada no ápice, margem sobreposta ciliada desde a base; lígula interna 0,1-0,3 mm compr., membranácea, pubérula, ápice ciliado; fímbrias presentes, não fusionadas, 2,2-21 $\mathrm{mm}$ compr., retas a sinuosas, amareladas a castanhas; lâmina 3,2-13,8 ×0,2-1,7 cm, face adaxial escabra, face abaxial pubescente, ápice escabro, margem escabra. Complementos de ramos com 20-72 ramos, 7-41 cm compr., 0,5-0,9 mm diâm.; ramos de segunda ordem ausentes; nós não proeminentes, castanhos. Folhas dos ramos 5-15 por ramo; bainha 1,3-3,1 cm × 1-2,2 mm, glabra a pubescente em direção ao ápice, por vezes hirsuta, margem sobreposta ciliada; aurículas ausentes; lígula externa $0,08-0,2 \mathrm{~mm}$ compr.; lígula interna $0,1-0,4 \mathrm{~mm}$ compr., pubérula; fímbrias presentes, não fusionadas, 0,6-6,3 mm compr., retas a sinuosas, por vezes 


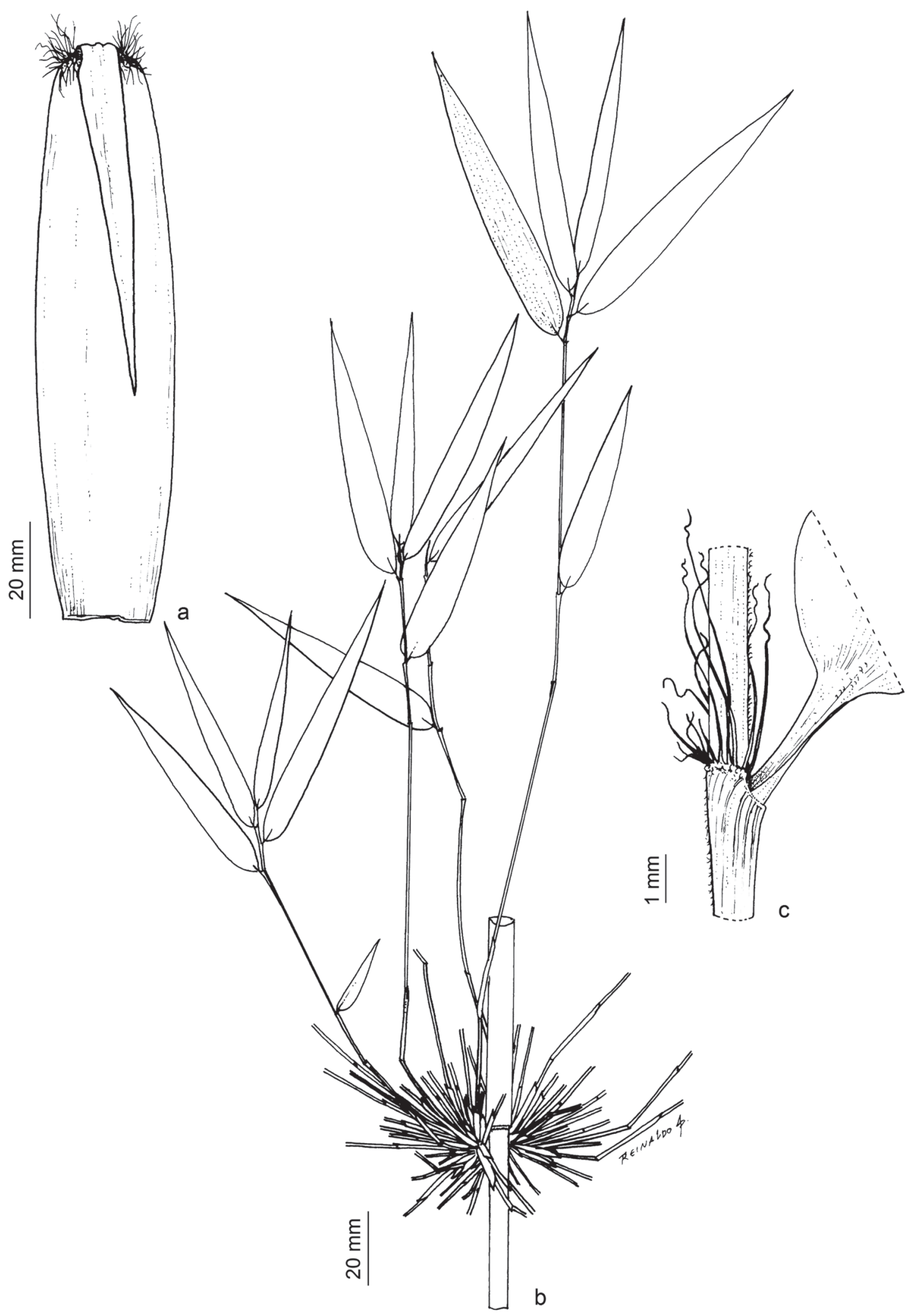

Figura 11. Merostachys leptophylla (R.V. Silva \& M.A. Cupertino 21). a. Folha do colmo. b. Complemento de ramo. c. Região ligular da folha do ramo com fimbrias. (Ilustrada por Reinaldo Pinto).

Figure 11. Merostachys leptophylla (R.V. Silva \& M.A. Cupertino 21). a. Culm leaf. b. Branch complement. c. Ligular region of leaf branches with fimbriae. (Illustrated by Reinaldo Pinto). 
encaracoladas, castanhas na base e amareladas em direção ao ápice; pseudopecíolo 1,1-2,7 mm compr., esverdeado a castanho, retorcido, pubescente a híspido; lâmina 4-9,9 × 0,5-1,5 cm, C:L = 6-13,8, lanceolada, face adaxial com 2-4 nervuras marginais escabras, glabra no restante, face abaxial glabra, base simétrica a assimétrica. Inflorescência pectinada, 2,8-3,5 cm compr., 5-7 espiguetas; pedúnculo subtendido pela bainha da última folha do ramo; raque velutina a tomentosa, bráctea estéril na base do racemo ausente. Espiguetas $8 \times 2,5 \mathrm{~mm}$, solitárias, 1-flora; pedicelo 1,1-1,5 mm compr., tomentoso; glumas depauperadas, não analisadas; lema $6 \times 4 \mathrm{~mm}, 15$-nervado, brilhante, glabro, margem ciliada no ápice, sem manchas escuras adaxialmente, mútico; pálea 7,5 ×4 mm, 10-nervada, brilhante, glabra, margem ciliada no ápice; extensão da ráquila $7 \mathrm{~mm}$ compr. Cariopse não vista.

Material examinado: BRASIL. Minas Gerais: Marliéria, Parque Estadual do Rio Doce, Trilha do Aníbal, 12-IV-1999, veg., Santos-Gonçalves et al. 94 (VIC); idem, 21-VI-1999, veg., Santos-Gonçalves et al. 142 (VIC); idem, 20-IX-1999, veg., SantosGonçalves et al. 200 (VIC); idem, 16-IV-2014, veg., R.V. Silva \& M.A. Cupertino 19 (VIC); idem, 16-IV-2014, veg., R.V. Silva \& M.A. Cupertino 21 (VIC).

Material adicional examinado: BRASIL. BAHIA: Ibicaraí, entre Ibicaraí e Floresta Azul, a $7 \mathrm{Km}$ de Ibicaraí, 3-IV-1974, fl., T.R. Soderstrom, G.F. Russel \& J. Hage 2106 (Type) (ISC, K, MO, SP, US). EsPírito SANTo: São Roque do Canaã, distrito São Jacinto, Militon, 16-X-2004, veg., L. Kollmann, A. Fontana, C.N. Fraga \& R.C. de Britto 7084 (MBML).

Merostachys leptophylla assemelha-se a $M$. calderoniana, e as características que as aproximam e distinguem são discutidas nos comentários desta espécie. O espécime coletado durante os trabalhos de campo está em estádio vegetativo. Ao analisar o material tipo, verificou-se que as inflorescências estavam depauperadas e possuíam pouquíssimas espiguetas; apenas poucos antécios que se encontravam desprendidos foram analisados justificando, assim, a ausência de dados sobre as glumas I e II na descrição acima.

Fenologia de floração: a espécie foi coletada em floração apenas em 1976, e a ilustração do material reprodutivo pode ser visualizada em Sendulsky (1995).
Distribuição: Merostachys leptophylla é citada para a Bahia (Sendulsky, 2001) e Espírito Santo (Flora do Brasil 2020) sendo aqui registrada, pela primeira vez para o Estado de Minas Gerais, onde ocorre na região Leste, sendo encontrada em sub-bosque e borda de vegetação caracterizada por Veloso et al. (1991) como Floresta Atlântica Estacional Semidecidual Submontana.

11. Merostachys ramosa Pianiss., Vinic.-Silva \& Clark, Phytotaxa 267 (3): 220. 2016.

Figura 12

Plantas arborescentes com colmos inicialmente eretos e posteriormente inclinando-se sobre a vegetação. Colmos 11-20 m compr. Entrenós 44-98 cm compr., cilíndricos, 0,8-3,5 cm diâm., verde com estrias amarelas, escabros, opacos; faixa infranodal de tricomas ausente; lúmen amplo, não preenchido por medula; parede 2,7-4 $\mathrm{mm}$ de espessura. Nós não proeminentes, castanhos a enegrecidos; franja de tricomas na linha nodal ausente. Folhas do colmo $28-53,7 \mathrm{~cm}$ compr.; bainha $16-41 \times 6,5-10 \mathrm{~cm}$, face adaxial glabra, brilhante, face abaxial esparsamente serícea, ápice escabro, margem ciliada no ápice; lígula interna 0,6-1,4 mm compr., membranácea, glabra, ápice ciliado; fímbrias presentes, não fusionadas, 3,6-7,8 mm compr., retas a sinuosas, enroladas no ápice, amareladas; lâmina 12-12,7 × $1 \mathrm{~cm}$, face adaxial escabra, face abaxial hirsuta, ápice escabro, margem escabra. Complementos de ramos com 125-850 ramos, 16-87 cm compr., 0,7-1,8 mm diâm.; ramos de segunda ordem presentes; nós não proeminentes, castanhos a enegrecidos. Folhas dos ramos 3-10 por ramo; bainha 1,5-4,3 $\mathrm{cm} \times 1,4-3,8 \mathrm{~mm}$, glabra, margem sobreposta ciliada; aurículas ausentes; lígula externa 0,1-0,2 mm compr.; lígula interna 0,1-0,3 mm compr., glabra; fímbrias presentes, não fusionadas, 2-7 mm compr., retas a sinuosas, por vezes enroladas no ápice, amareladas a castanhas; pseudopecíolo 2-3,8 mm compr., verde-escuro a castanho, retorcido, glabro a pubescente; lâmina 5-13 × 0,7-1,7 cm, C:L = 6-14,6, lanceolada, face adaxial com 3-5 nervuras marginais escabras, ápice glabro, escabro no restante, face abaxial glabra, ápice escabro, tufo de tricomas híspidos na base presente, base simétrica a assimétrica. Inflorescência não vista.

Material examinado: BRASIL. Minas Gerais: Araponga, Parque Estadual da Serra do Brigadeiro, Serra das Cabeças, trilha do mamute, 21-I-2014, veg., E.M. Pianissola \& D.F. Parma 38 (Type) (VIC); idem, 


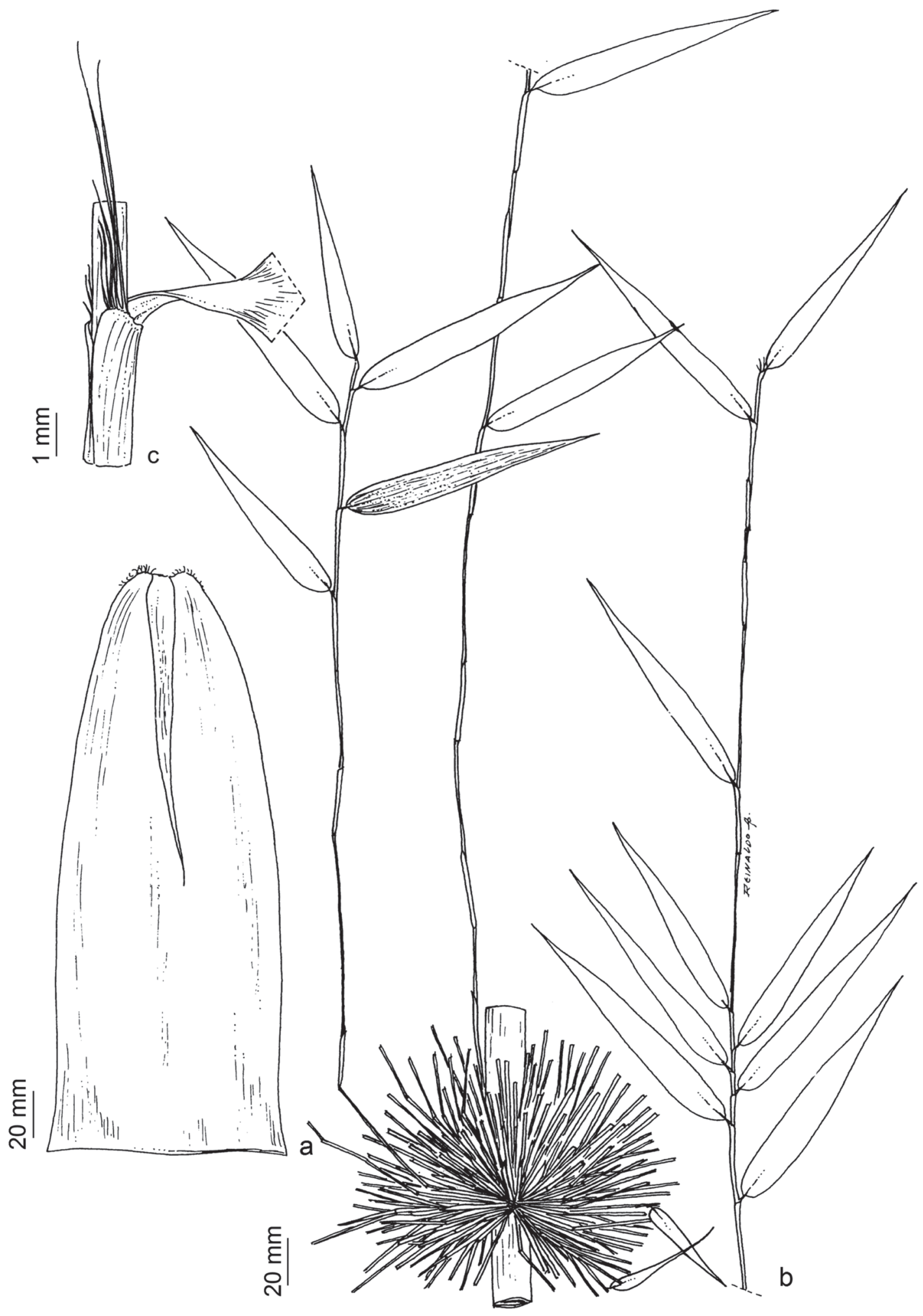

Figura 12. Merostachys ramosa. a. (E.M. Pianissola \& D.F. Parma 38). Folha do colmo. b-c. (M.M. Picanço, D.F. Parma \& E.P. Machado 24). b. Complemento de ramo com ramos vegetativos e folhas. c. Região ligular da folha do ramo com fímbrias. (Ilustrada por Reinaldo Pinto).

Figure 12. Merostachys ramosa. a. (E.M. Pianissola \& D.F. Parma 38). Culm leaf. b-c. (M.M. Picanço, D.F. Parma \& E.P. Machado 24). b. Branch complement with vegetative branches and leaves. c. Ligular region of foliage leaf with fimbriae. (Illustrated by Reinaldo Pinto). 
trilha do Carvão, 9-IX-2013, veg., M.M. Picanço, D.F. Parma \& E.P. Machado 24 (Type) (BHCB, ISC, SP, US, VIC).

Merostachys ramosa distingue-se de todas as outras espécies do gênero pela grande quantidade de ramos (125-850) no complemento de ramo.

Fenologia de floração: a espécie foi registrada, até o momento, somente em estádio vegetativo.

Distribuição: é registrada para a região Sudeste de Minas Gerais, onde foi coletada somente no Parque Estadual da Serra do Brigadeiro, em sub-bosque e borda de vegetação caracterizada por Veloso et al. (1991) como Floresta Atlântica Estacional Semidecidual Montana.

12. Merostachys riedeliana Rupr., Fl. Bras. (Martius) 2 (3): 213. 1880.

Figura 13

Plantas arborescentes com colmos inicialmente eretos e posteriormente inclinando-se sobre a vegetação. Colmos 13-15 m compr. Entrenós 23-55 cm compr., cilíndrico, 1-3 cm diâm., verde-amarelados, glabros, opacos; faixa infranodal de tricomas velutinos presente, 0,4-0,9 mm compr.; lúmen amplo, não preenchido por medula; parede 1-2,8 mm de espessura. Nós não proeminentes, castanhos; franja de tricomas na linha nodal ausente. Folhas do colmo $26,3-44,5 \mathrm{~cm}$ compr.; bainha $21-32,5 \times 3-16,6 \mathrm{~cm}$, face adaxial glabra, brilhante, face abaxial com uma camada de cera, esparsamente hirsuta e coberta por tricomas esbranquiçados, brilhantes e esparsos, margem ciliada; lígula interna 1,6-2,8 mm compr., membranácea, pubescente a tomentosa, ápice ciliado; fímbrias presentes, não fusionadas, 1,2-22,6 mm compr., retas a sinuosas, enroladas no ápice, amareladas a avermelhadas; lâmina 5,3-12 × 1-2 cm, face adaxial glabra a pubescente, às vezes esparsamente hirsuta, ápice escabro, face abaxial glabra a pubescente, às vezes esparsamente hirsuta, margem escabra em direção ao ápice. Complementos de ramos com 7-46 ramos, 19-110 cm compr., 3-5 mm diâm.; ramos de segunda ordem ausentes; nós não proeminentes, castanhos. Folhas dos ramos 4-15 por ramo; bainha 1,9-16,7 cm × 3,2-12 mm, pubescente a híspida, às vezes glabra ou esparsamente hirsuta, margem sobreposta ciliada; aurículas ausentes; lígula externa 0,1-0,5 mm compr.; lígula interna 0,1-2,7 mm compr., pubescente; fímbrias presentes, não fusionadas, 2,5-24 mm compr., retas a sinuosas, geralmente enroladas no ápice, amareladas a avermelhadas; pseudopecíolo 2,5-7,7 mm compr., esverdeado a castanho, reto a retorcido, pubescente a levemente híspido, às vezes glabro; lâmina 5,5-26,5 × 1-4,7 cm, $\mathrm{C}: \mathrm{L}=3,4-7$, lanceolada, face adaxial com 2-4 nervuras marginais escabras, glabra no restante, face abaxial coberta com diminutos tricomas estrigosos antrorsos, às vezes esparsamente hirsuta, região marginal oposta à estria discolor híspida, base simétrica a assimétrica. Inflorescência pectinada, 3,8-16,5 cm compr., 12-47 espiguetas; pedúnculo subtendido pela bainha da última folha do ramo; raque tomentosa, bráctea estéril na base do racemo ausente. Espiguetas 15-26 × 1,5-3,5 mm, solitárias, 1-2-flora; pedicelo 1-2 mm, tomentoso; gluma I 4-8 × 1-2 mm, 1-4 nervada, serícea, margem ciliada, mútica; gluma II 17-25,5 × 4-6,5 mm, 12-18-nervada, híspida na base das nervuras, pubescente a serícea no restante, margem ciliada apicalmente, um dos lados da margem geralmente ciliado desde a base, aristada, arista 1-3 mm compr., por vezes ultrapassando a extensão do antécio, ângulo obtuso entre gluma II e raque; lema 15-19,2 × 6-8 mm, 19-25-nervado, opaco, seríceo, margem ciliada em direção ao ápice, ápice com uma franja de tricomas, com manchas escuras adaxialmente, mútico; pálea 15-18 × 4-6 mm, 10-14-nervada, opaca, inicialmente pubérula e serícea em direção ao ápice, às vezes totalmente pubérula; extensão da ráquila 11-18 mm compr. Cariopse não vista.

Material examinado: BRASIL. Minas Gerais: Belo Horizonte, Jardim Botânico, 3-I-1934, fl., M. Barreto 2959 (BHCB); Juiz de Fora, Campus da UFJF, estrada de terra que liga ao Dom Orione, 22-I-1993, fl., $M$. Eiterer \& D. Sette 123 (VIC); Marliéria, Parque Estadual do Rio Doce, Trilha do Aníbal, 16-IV-2014, veg., R.V. Silva \& M.A. Cupertino 20 (VIC); Idem, 12-IV-1999, fl., A.P. Santos-Gonçalves et al. 95 (VIC); Idem, 20-XII-1999, fl., A.P. Santos-Gonçalves et al. 286 (VIC).

Material adicional examinado: BRASIL. SÃo PAULO: São Carlos, I-1834, fl., Riedel 1856 (Type) (G foto, NY foto, P foto, US).

Merostachys riedeliana assemelha-se a Merostachys aff. riedeliana pelo número de espiguetas por inflorescência, pelo comprimento da arista da gluma II em relação ao antécio e pela presença de uma franja de tricomas no ápice do lema. No entanto, difere pela presença de uma faixa infranodal de tricomas 


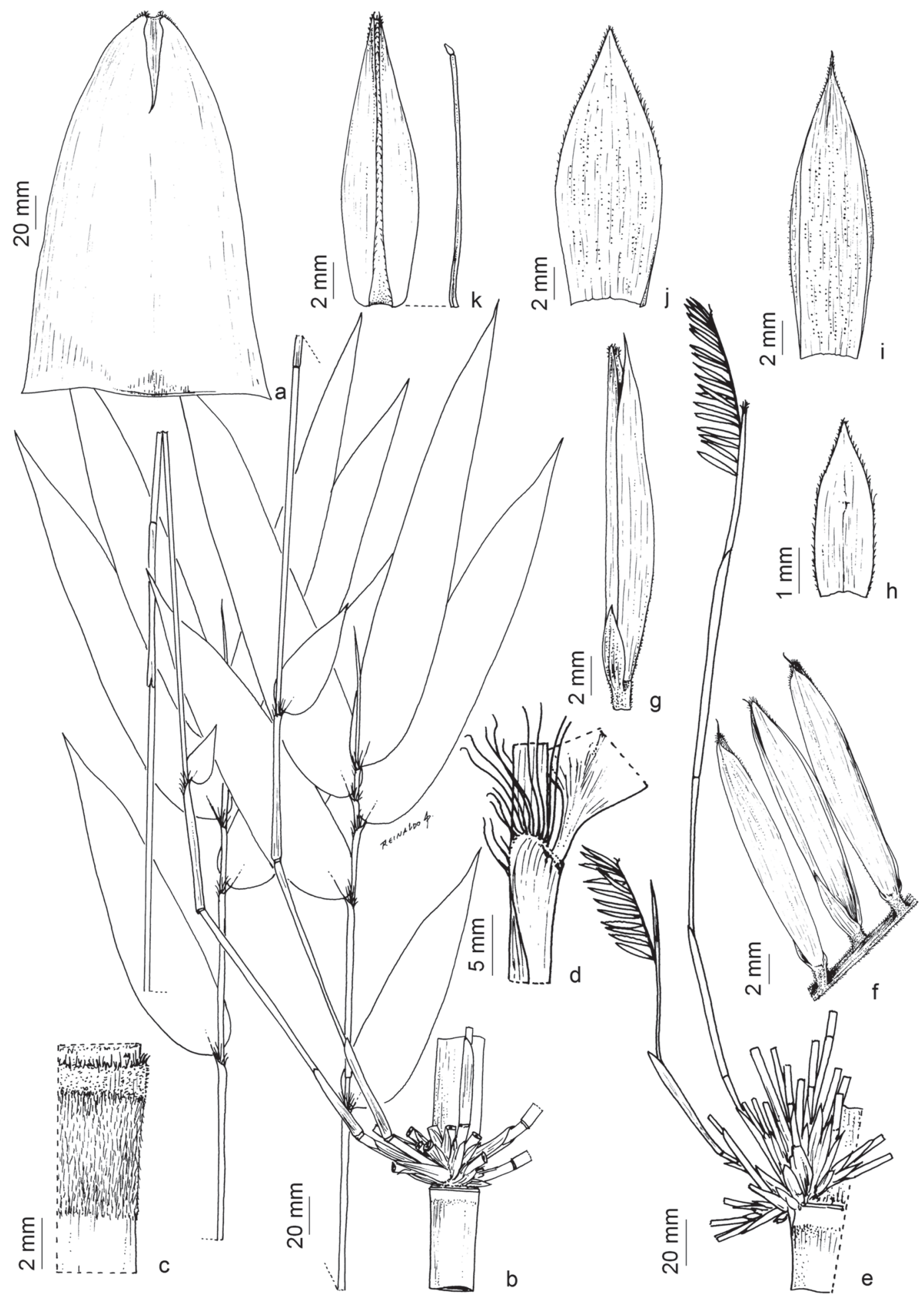

Figura 13. Merostachys riedeliana. a-d. (R.V. Silva \& M.A. Cupertino 20). e-k. (A.P. Santos-Gonçalves et al. 286). a. Folha do colmo. b. Complemento de ramo com ramos vegetativos e folhas. c. Faixa infranodal de tricomas velutinos. d. Região ligular da folha do ramo com fímbrias. e. Complemento de ramo com ramos floríferos. f. Seção da inflorescência. g. Espigueta. h. Gluma I. i. Gluma II. j. Lema. k. Pálea e extensão da ráquila. (Ilustrada por Reinaldo Pinto).

Figure 13. Merostachys riedeliana. a-d. (R.V. Silva \& M.A. Cupertino 20). e-k. (A.P. Santos-Gonçalves et al. 286). a. Culm leaf. b. Branch complement with vegetative branches and leaves. c. Infranodal band of velutinous trichomes. $d$. Ligular region of foliage leaf with fimbriae. e. Branch complement with floriferous branches. f. Section of the inflorescence. g. Spikelet. h. Lower glume. i. Upper glume. j. Lemma. k. Palea and rachilla extension. (Illustrated by Reinaldo Pinto). 
velutinos e por não apresentar um tufo de tricomas híspidos na base da face abaxial da lâmina das folhas dos ramos, além do número de nervuras na gluma I. Esta espécie também se assemelha a M. claussenii var. mollior, e esta questão já foi discutida nos comentários dessa espécie.

Fenologia de floração: a espécie foi coletada com flor em 1834, 1934, 1987, 1993, 1994, 1995, 1996 e 1999, o que sugere um ciclo reprodutivo em torno de 53 anos.

Distribuição: Judziewicz et al. (1999) mencionam que M. riedeliana ocorre na porção Leste do Brasil. Na obra original, é citada sua ocorrência para o Estado de São Paulo. Santos-Gonçalves et al. (2006) registraram a espécie para Minas Gerais. De acordo com o presente estudo, $M$. riedeliana pode ser encontrada nas regiões Central, Leste e Sudeste do Estado de Minas Gerais, em sub-bosque e borda de vegetação caracterizada por Veloso et al. (1991) como Floresta Estacional Semidecidual Montana e Submontana.

\section{Merostachys skvortzovii Send., Novon 5 (1): 94.} 1995.

Figura 14

Plantas arborescentes com colmos inicialmente eretos e posteriormente inclinando-se sobre a vegetação. Colmos 4-6 m compr. Entrenós incompletos, cilíndricos, 1,5-3 cm diâm., verdeamarelados, escabros, opacos; faixa infranodal de tricomas velutinos presente, 2-3,6 mm compr.; lúmen amplo, não preenchido por medula; parede 1,2-2 $\mathrm{mm}$ de espessura. Nós não proeminentes, castanhos; franja de tricomas na linha nodal ausente. Folhas do colmo não vistas. Complementos de ramos 27-51 (-200) ramos, 21-48 cm comp., 0,9-1,3 mm diâm.; ramos de segunda ordem ausentes; nós não proeminentes, castanhos. Folhas dos ramos (5-) 7-10 por ramo; bainha 5,3-8,4 $\mathrm{cm} \times 5-9 \mathrm{~mm}$, glabra ou esparsamente hirsuta, margem sobreposta ciliada; aurículas ausentes; lígula externa 0,1-0,4 mm compr.; lígula interna 0,1-2,4 $\mathrm{mm}$ compr., pubescente; fímbrias presentes, não fusionadas, $2-8 \mathrm{~mm}$ compr., retas a onduladas, castanhas; pseudopecíolo 2,5-3 mm compr., esverdeado a castanho, retorcido, glabro a puberulento; lâmina 7,5-9,5 (-11) × 1,2-1,8 cm, $\mathrm{C}: \mathrm{L}=4,5-8$, lanceolada, face adaxial com 2-3 nervuras marginais escabras, ápice escabro, glabra no restante, face abaxial glabra, com um tufo de tricomas híspidos na base, base simétrica a assimétrica. Inflorescência pectinada, 1,5-5,2 cm compr., 24-30 espiguetas; pedúnculo subtendido pela bainha da última folha do ramo; raque velutina, bráctea estéril na base do racemo ausente. Espiguetas 10-11 × 1,8-3 mm, solitárias, 1-flora; pedicelo 0,8-1,6 mm compr., velutino; gluma I ca. $2 \times 1-1,5 \mathrm{~mm}, 1$-nervada, pubescente, margem ciliada, mútica; gluma II 8,5-9,5 × 3,5-4 mm, 10-12 nervada, pubescente, margem ciliada em direção ao ápice, mucronada, ângulo obtuso entre gluma II e raque; lema 9-9,5 × 5-5,5 mm, 12-15 nervado, opaco, pubescente, margem ciliada apicalmente, um dos lados da margem ciliado desde a base, sem manchas escuras adaxialmente, mucronado; pálea 9,5-10 × 4-5 mm, 8-10 nervada, opaca, pubérula, margem ciliada apicalmente; extensão da ráquila ca. 7,5 mm compr. Cariopse 4,5-6 $\times 2 \mathrm{~mm}$, oval, rostrada, castanha, hilo conspícuo.

Material examinado: BRASIL. Minas Gerais: Tiradentes, Rodovia 265, Barbacena em direção à Tiradentes, 5-III-2014, fl., A.P. Santos-Gonçalves 669 (VIC); Viçosa, Universidade Federal de Viçosa, 2014, fl., A.A. Miranda s.n. (VIC48750).

Material adicional examinado: BRASIL. São PAULO: São Paulo, Parque do Estado e Jardim Botânico, 20-X-1973, fl., Skvortzov s.n. (Type) (SP120954).

Merostachys skvortzovii assemelha-se a $M$. claussenii var. mollior, e os caracteres que as aproximam e diferem são discutidos nos comentários desta última espécie.

Fenologia de floração: a espécie foi coletada com flor em 1941,1971, 1972, 1973, 1974 e 2014, o que sugere um ciclo reprodutivo de 30-40 anos.

Distribuição: Merostachys skvortzovii é registrada para os Estados de São Paulo, Paraná e Rio Grande do Sul (Sendulsky, 1995) e Minas Gerais (Parma et al. 2016b), onde foi coletada na região Sudeste em borda de vegetação caracterizada por Veloso et al. (1991) como Floresta Estacional Semidecidual Montana.

\section{Merostachys tatianae Santos-Gonç., Carv.-Okano} \& Filg., Syst. Bot. 37(4): 938. 2012.

\section{Figura 15}

Plantas arborescentes com colmos inicialmente eretos e posteriormente inclinando-se sobre a vegetação. Colmos 10-17 m compr. Entrenós 30-108 cm compr., cilíndricos, 2,7-4,7 cm diâm., verde-amarelados opacos, híspidos, tricomas urentes; faixa infranodal de tricomas ausente; lúmen amplo, não preenchido por medula; parede 0,9-2,9 mm de 


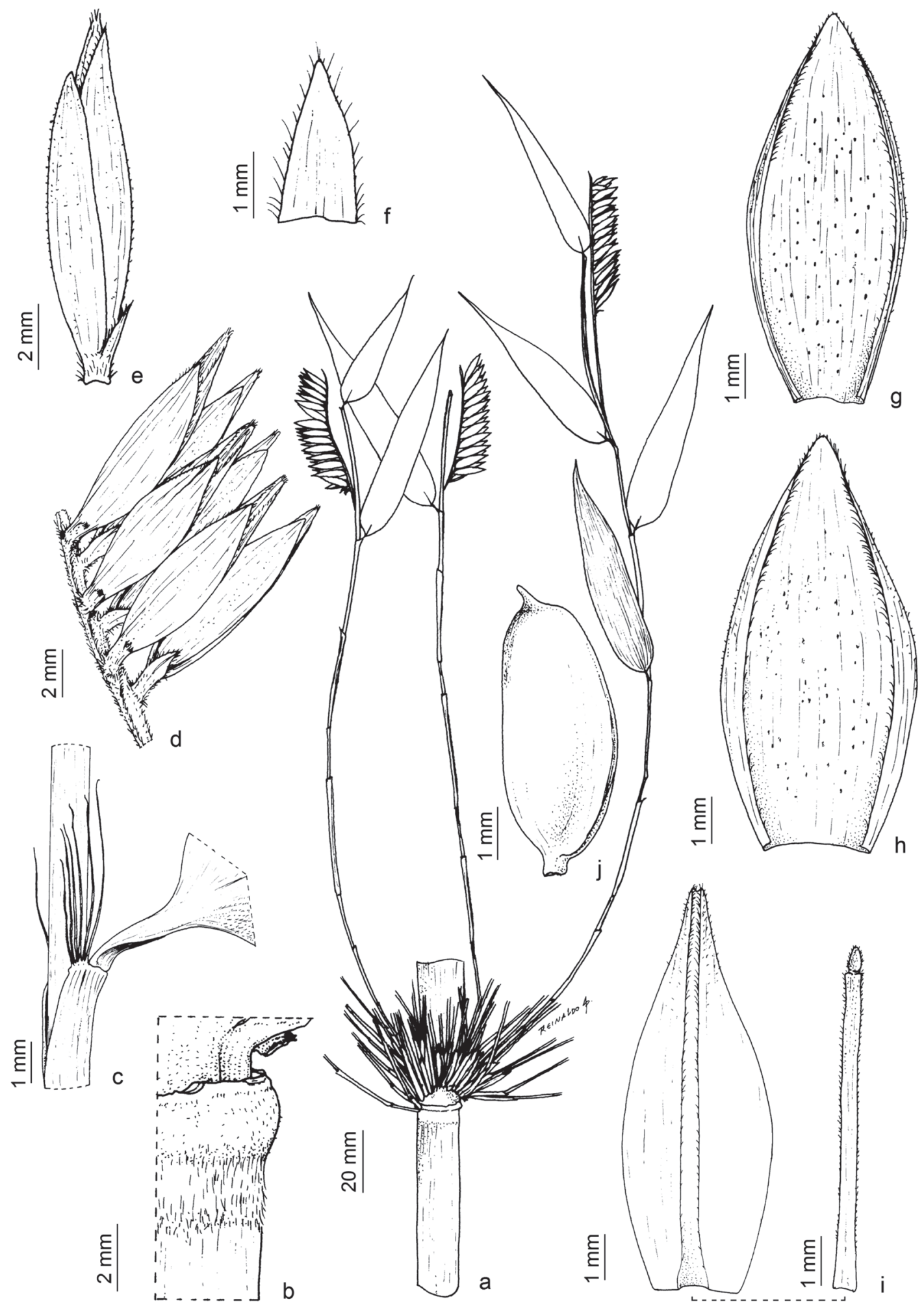

Figura 14. Merostachys skvortzovii. a-i (Miranda s.n. VIC48750). a. Complemento de ramos com ramos floríferos. b. Faixa infranodal de tricomas velutinos. c. Região ligular da folha do ramo com fímbrias. d. Seção da inflorescência. e. Espigueta. f. Gluma I. g. Gluma II. h. Lema. i. Pálea e extensão da ráquila. j. (A.P. Santos-Gonçalves 669). Cariopse. (Ilustrada por Reinaldo Pinto).

Figure 14. Merostachys skvortzovii. a-i (Miranda s.n. VIC48750). a. Branch complement with floriferous branches. b. Infranodal band of velutinous trichomes. c. Ligular region of foliage leaf with fimbriae. d. Section of the inflorescence. e. Spikelet. f. Lower glume. g. Upper glume. h. Lemma. i. Palea and rachilla extension. j. (A.P. Santos-Gonçalves 669). Caryopsis. (Illustrated by Reinaldo Pinto). 


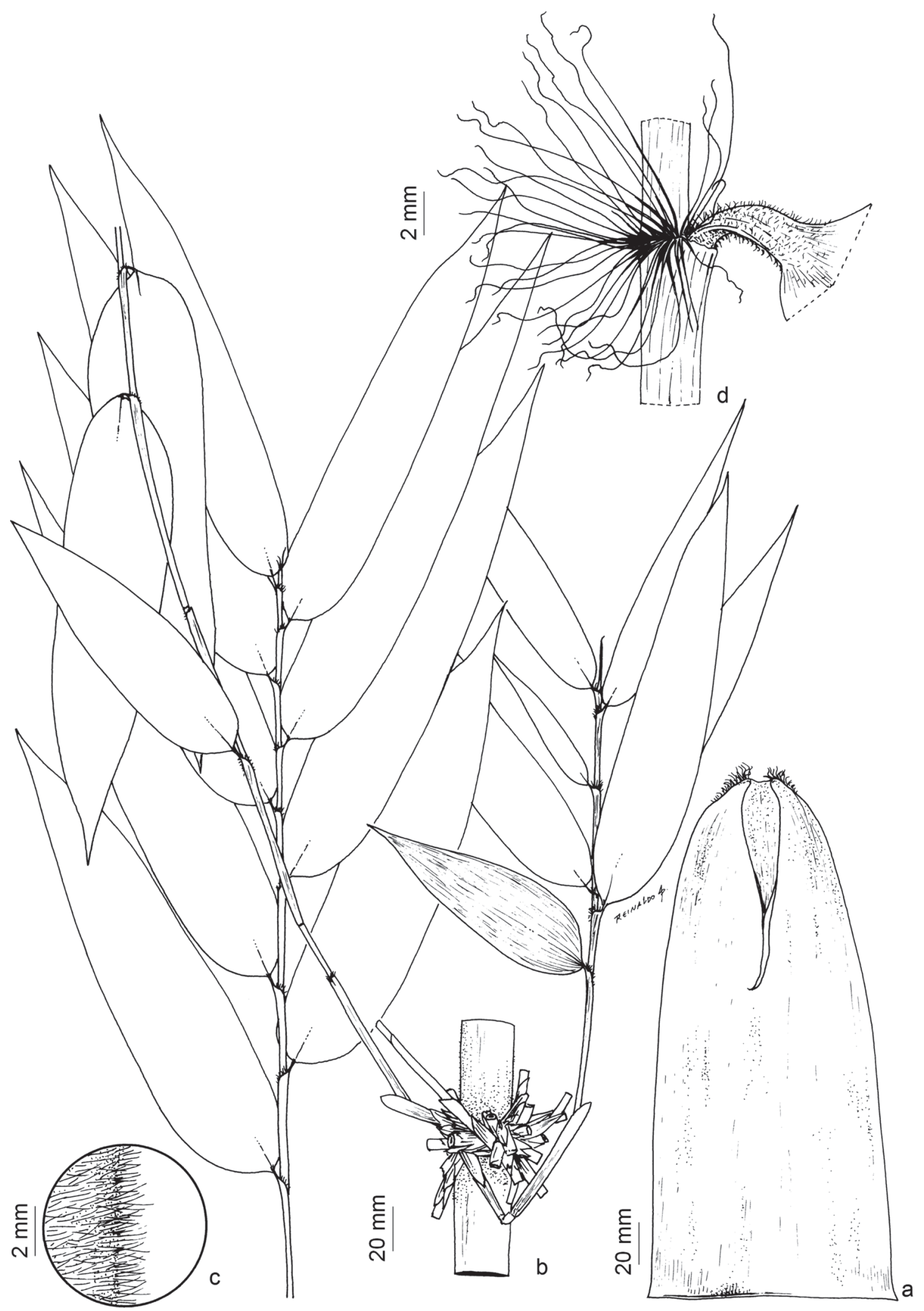

Figura 15. Merostachys tatianae (R.V. Silva \& M.A. Cupertino 18). a. Folha do colmo. b. Complemento de ramos. c. Detalhe dos tricomas híspidos do entrenó. d. Região ligular da folha dos ramos com fímbrias. (Ilustrada por Reinaldo Pinto).

Figure 15. Merostachys tatianae (R.V. Silva \& M.A. Cupertino 18). a. Culm leaf. b. Branch complement. c. Hispid trichomes on the internode. d. Ligular region of foliage leaf with fimbriae. (Illustrated by Reinaldo Pinto). 
espessura. Nós não proeminentes, castanhos; franja de tricomas na linha nodal ausente. Folhas do colmo $32-63,5 \mathrm{~cm}$ compr.; bainha 22-42,5 × 11,2-19,5 cm, face adaxial brilhante, poucos tricomas adpressos e esparsos, face abaxial híspida, margem ciliada no ápice, margem sobreposta ciliada desde a base; lígula interna 1-2,5 mm compr., membranácea, pubescente, ápice ciliado; fímbrias presentes, não fusionadas, 1-20 mm compr., retas a sinuosas, enroladas no ápice, amareladas a avermelhadas; lâmina 10-21 × 0,7-2,5 cm, faces adaxial e abaxial híspidas, margem escabra. Complementos de ramos com 13-48 ramos, 30,5-126,5 cm compr., 2,2-5,5 mm diâm.; ramos de segunda ordem ausentes; nós não proeminentes, castanhos. Folhas dos ramos 7-22 por ramo; bainha 4,4-11,5 $\mathrm{cm} \times 3,2-11,3 \mathrm{~mm}$, pubescente a híspida, às vezes levemente escabra, margem sobreposta ciliada; aurículas ausentes; lígula externa 0,1-0,4 mm compr.; lígula interna $0,2-1 \mathrm{~mm}$ compr., pubescente; fímbrias presentes, não fusionadas, 0,5-22,3 mm compr., retas a sinuosas, enroladas no ápice, avermelhadas; pseudopecíolo 2,6-11 mm compr., castanho, reto a retorcido, tomentoso; lâmina 5,3-30 × 0,8-6,4 cm, C:L=3-8, lanceolada, face adaxial com 3-7 nervuras marginais escabras, margem oposta com uma faixa de diminutos tricomas estrigosos antrorsos em direção ao ápice, face abaxial com uma faixa de diminutos tricomas estrigosos antroros em direção ao ápice próxima à estria discolor, região marginal oposta à estria discolor híspida, glabra no restante, tufo de tricomas híspidos na base presente, base assimétrica. Inflorescência pectinada, 8-13 cm compr., 30-90 espiguetas; pedúnculo subtendido pela bainha da última folha do ramo; raque velutina, bráctea estéril na base do racemo ausente. Espiguetas 11,5-17,5 × 2-3,5 mm, aos pares, 1-2-flora; pedicelo 1-3 mm compr., glabro a tomentoso; gluma I 4-5 × 2-2,5 mm, 4-5-nervada, serícea, margem ciliada, aristada, arista 0,7-1 mm compr.; gluma II 7-8,5 × 4-5 mm, 15-19-nervada, serícea, margem ciliada, aristada, arista 0,7-1 mm compr., manchas escuras adaxialmente, ângulo agudo entre gluma II e raque; lema 11-14 × 7-8 mm, 22-28-nervado, opaco, seríceo a tomentoso, margem ciliada, sem manchas escuras adaxialmente, aristado, arista $1 \mathrm{~mm}$ compr.; pálea 8-11,5 × 3-5 mm, 10-12-nervada, opaca, serícea. Cariopse não vista.

Material examinado: BRASIL. Minas Gerais: Marliéria, Estrada Principal de acesso ao Restaurante, 15-IV-2014, veg., R.V. Silva \& M.A. Cupertino 18 (VIC); Idem, Trilha do Aníbal, 23-VIII-1999, fl., A.P. Santos-Gonçalves et al. 191 (Type) (VIC); idem,
28-II-2002, fl., Santos-Gonçalves et al. 426 (UEC); idem, Península da Lagoa Dom Helvécio, ao longo da Estrada, 17-IX-1975, veg., E.P. Heringer \& G. Eiten 15017 (UB); Viçosa, Fazenda Bom Sucesso, Mata do Seu Nico, 27/VIII/2014, veg., D.F. Parma \& R.V. Silva 40 (VIC); idem, 10-X-2014, veg., D.F. Parma \& Celso Antônio 58 (VIC); idem, Escola de Agricultura de Viçosa, 15-VI-1934, fl., M. Barreto s.n. (IAC5227).

Merostachys tatianae caracteriza-se por apresentar entrenó e face abaxial da bainha da folha do colmo cobertos por tricomas híspidos, urentes.

Fenologia de floração: a espécie foi coletada em estádio reprodutivo em 1934, 1935 e 2002, o que sugere um intervalo entre florações de 68 anos; no entanto, são necessários mais estudos para esclarecer o ciclo reprodutivo desta espécie. A ilustração do material reprodutivo pode ser encontrada em SantosGonçalves et al. (2012).

Distribuição: a espécie é registrada apenas para Minas Gerais, onde ocorre em sua região Sudeste (SantosGonçalves et al. 2012) em sub-bosque e borda de vegetação caracterizada por Veloso et al. (1991) como Floresta Atlântica Estacional Semidecidual Montana e Floresta Atlântica Estacional Semidecidual Submontana.

15. Merostachys ternata Nees, Fl. Bras. Enum. P1. 2: 529. 1829.

Figura 16

Plantas arborescentes com colmos inicialmente eretos e posteriormente inclinando-se sobre a vegetação. Colmos 8-10 m compr. Entrenós $33-102 \mathrm{~cm}$ compr., cilíndricos, 1-2,8 cm diâm., amarelo com estrias verdes, escabros, opacos; faixa infranodal de tricomas velutinos presente, 3,3-5 mm compr.; lúmen amplo, não preenchido por medula; parede com 1-1,3 mm de espessura. Nós não proeminentes, castanhos; franja de tricomas na linha nodal ausente. Folhas do colmo 45-65,5 cm compr.; bainha 34,5-45,5 × 6,5-9 cm, face adaxial glabra, brilhante, face abaxial escabra, lanosa, margem ciliada em direção ao ápice; lígula interna 0,9-1,9 mm compr., membranácea, pubescente, ápice ciliado; fímbrias presentes, não fusionadas, 3,3-31,4 mm compr., retas a sinuosas, geralmente enroladas no ápice, amareladas a avermelhadas; lâmina 10,5-20 × 0,8-1,3 cm, face adaxial escabra, às vezes esparsamente hirsuta, face abaxial escabra, margem escabra. Complementos de 


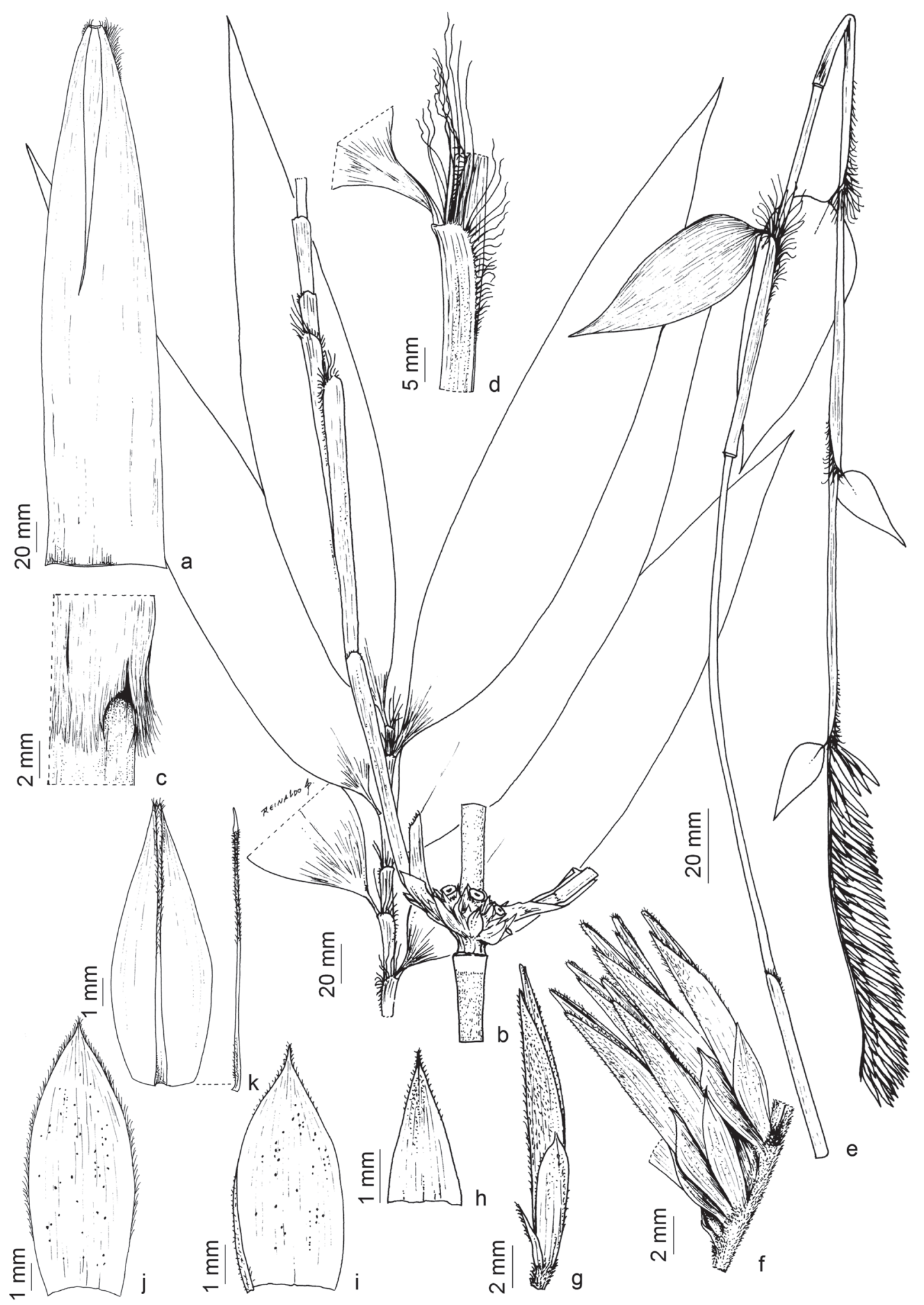

Figura 16. Merostachys ternata. a-d. (R.V. Silva et al. 30). e-k. (Folli 3316). a. Folha do colmo. b. Complemento de ramo com ramos vegetativos e folhas. c. Faixa infranodal de tricomas velutinos. d. Região ligular da folha do ramo com fímbrias. e. Ramo florífero. f. Seção da inflorescência. g. Espigueta. h. Gluma I. i. Gluma II. j. Lema. k. Pálea e extensão da ráquila. (Ilustrada por Reinaldo Pinto).

Figure 16. Merostachys ternata. a-d. (R.V. Silva et al. 30). e-k. (Folli 3316). a. Culm leaf. b. Branch complement with vegetative branches and leaves. c. Infranodal band of velutinous trichomes. d. Ligular region of foliage leaf with fimbriae. e. Floriferous branch. f. Section of the inflorescence. g. Spikelet. h. Lower glume. i. Upper glume. j. Lemma. k. Palea and rachilla extension. (Illustrated by Reinaldo Pinto). 
ramos com 3-7 ramos, 45-103,5 cm compr., 4,6-7 mm diâm.; ramos de segunda ordem ausentes; nós não proeminentes, castanhos. Folhas dos ramos 6-20 por ramo; bainha 4,5-18,3 $\mathrm{cm} \times 4,5-15,2 \mathrm{~mm}$, glabra a lanosa, às vezes esparsamente hirsuta, margem sobreposta ciliada em direção ao ápice; aurículas ausentes; lígula externa $0,2-0,8 \mathrm{~mm}$ compr.; lígula interna 1-2,7 mm compr., glabra a pubérula; fímbrias presentes, não fusionadas, 2,8-57 mm compr., retas a sinuosas, geralmente enroladas no ápice, amareladas a avermelhadas; pseudopecíolo 4,4-12,8 mm compr., castanho-claro, retorcido, glabro a pubescente; lâmina 20-42 × 2-10,7 cm, C:L = 4-6,3, lanceolada, face adaxial com 2-4 nervuras marginais escabras, ápice escabro, glabro no restante, face abaxial com uma faixa de diminutos tricomas estrigosos antrorsos em direção ao ápice, próxima à estria discolor, glabra no restante, base assimétrica. Inflorescência pectinada, $8-12 \mathrm{~cm}$ compr.; pedúnculo subtendido pela bainha da última folha do ramo; raque tomentosa, bráctea estéril na base do racemo ausente, 90-140 espiguetas. Espiguetas 13-16,5 × 1,5-2 mm, agrupadas aos pares ou em tríades, 1-flora; pedicelo $1 \mathrm{~mm}$ compr., tomentoso; gluma I 3-5 × 1-2 mm, 1-3 nervada, pubescente a serícea, margem ciliada, aristada, arista 0,5-1 mm compr.; gluma II 6,5-8 × 3-4 mm, 9-15-nervada, pubescente, margem ciliada, aristada, arista $0,5-1 \mathrm{~mm}$ compr., ângulo obtuso entre gluma II e raque; lema 10,5-14,5 × 5-6 mm, 17-27-nervado, opaco, híspido em direção à margem, seríceo no restante, margem ciliada em direção ao ápice, com manchas escuras adaxialmente, aristado, arista 0,5-1 mm compr.; pálea 10-14 × 4-5 mm, 8-12 nervada, opaca, pubérula no ápice, glabra no restante, margem ciliada no ápice; extensão da ráquila 10-13 mm compr. Cariopse não vista.

Material examinado: BRASIL. Minas Gerais: Marliéria, Parque Estadual do Rio Doce, trilha da Lagoa Preta, 13-IV-1999, veg., A.P. Santos-Gonçalves et al. 119 (VIC); idem, 23-VI-1999, veg., A.P. SantosGonçalves 161 (VIC); idem, 28-VII-1999, veg., A.P. Santos-Gonçalves 188 (VIC); idem, 22-IX-1999, veg., A.P. Santos-Gonçalves et al. 205 (VIC); idem, 3-XII-1999, veg., A.P. Santos-Gonçalves et al. 278 (VIC); Santa Maria do Salto, Parque Estadual do Alto Cariri, Fazenda Retori, próximo à beira da estrada em direção à comunidade de Talismã, 15-V-2014, veg., R.V. Silva, J.I. Silva, A. Souza \& D.P. Santos 30 (VIC).

Material adicional selecionado: BRASIL. EsPírITO SANTO: Linhares, Reserva Natural da Vale, 10-XII-1998, fl., D.A. Folli 3316 (CVRD). Santa Catarina: Ilhota, Parque Botânico do Morro Baú, 6-VI-1963, fl., Reitz \& Klein 14952 (UB). São Paulo, Pariquera-Açu, Estação Experimental do IAC, 23-VI-1998, fl., R.B. Torres et al. 497 (VIC); sem localidade, sem data, fl., Martius 1818 (US).

Merostachys ternata assemelha-se, dentre as espécies catalogadas na área de estudo, a Merostachys ximenae e Merostachys aff. burmanii pela presença de espiguetas agrupadas aos pares ou tríades; difere, no entanto, por apresentar complementos de ramos com um número menor de ramos, fímbrias das folhas dos ramos com maior comprimento, entrenó com menor diâmetro, inflorescências pectinadas e espiguetas maiores.

Fenologia de floração: neste estudo, registrou-se a presença de material reprodutivo em coletas de 1963, 1966 e 1998, sugerindo, apesar da necessidade de mais informações sobre a floração da espécie, um ciclo reprodutivo de, aproximadamente, 32 anos.

Distribuição: Merostachys ternata é citada para São Paulo, Rio de Janeiro e Minas Gerais, de acordo com Nees (1829). McClure \& Smith (1967) mencionam que a espécie ocorre de Minas Gerais a Santa Catarina. Renvoize (1984) e Schimdt \& Longhi-Wagner (2008) citam a espécie para a Bahia e Rio Grande do Sul, respectivamente. Em Minas Gerais, distribui-se pelas regiões Sudeste e Nordeste, onde é encontrada no subbosque e borda de vegetação caracterizada por Veloso et al. (1991) como Floresta Atlântica Estacional Semidecidual Montana e Floresta Atlântica Estacional Semidecidual Submontana.

16. Merostachys ximenae Parma, Vinic.-Silva \& Santos-Gonç., Phytotaxa. 267 (3): 223. 2016. Figura17

Plantas arborescentes com colmos inicialmente eretos, posteriormente inclinando-se sobre a vegetação. Colmos 2-15 m compr. Entrenós 30,5-86 cm compr., cilíndricos, 0,5-3 cm diâm., verde amarelados, coberto por tricomas lanosos esparsos, opacos; faixa infranodal de tricomas lanosos presente, 2-13 mm compr.; lúmen amplo, não preenchido por medula; parede 1-2,4 $\mathrm{mm}$ de espessura. Nós proeminentes, castanhoescuros a enegrecidos; franja de tricomas na linha nodal ausente. Folhas do colmo 19,5-45 cm compr.; bainha 13,2-32,6 × 2,4-12,5 cm, face adaxial glabra, brilhante, face abaxial lanosa, esparsamente hirsuta, ápice escabro; lígula interna 0,5-3,4 mm compr., 


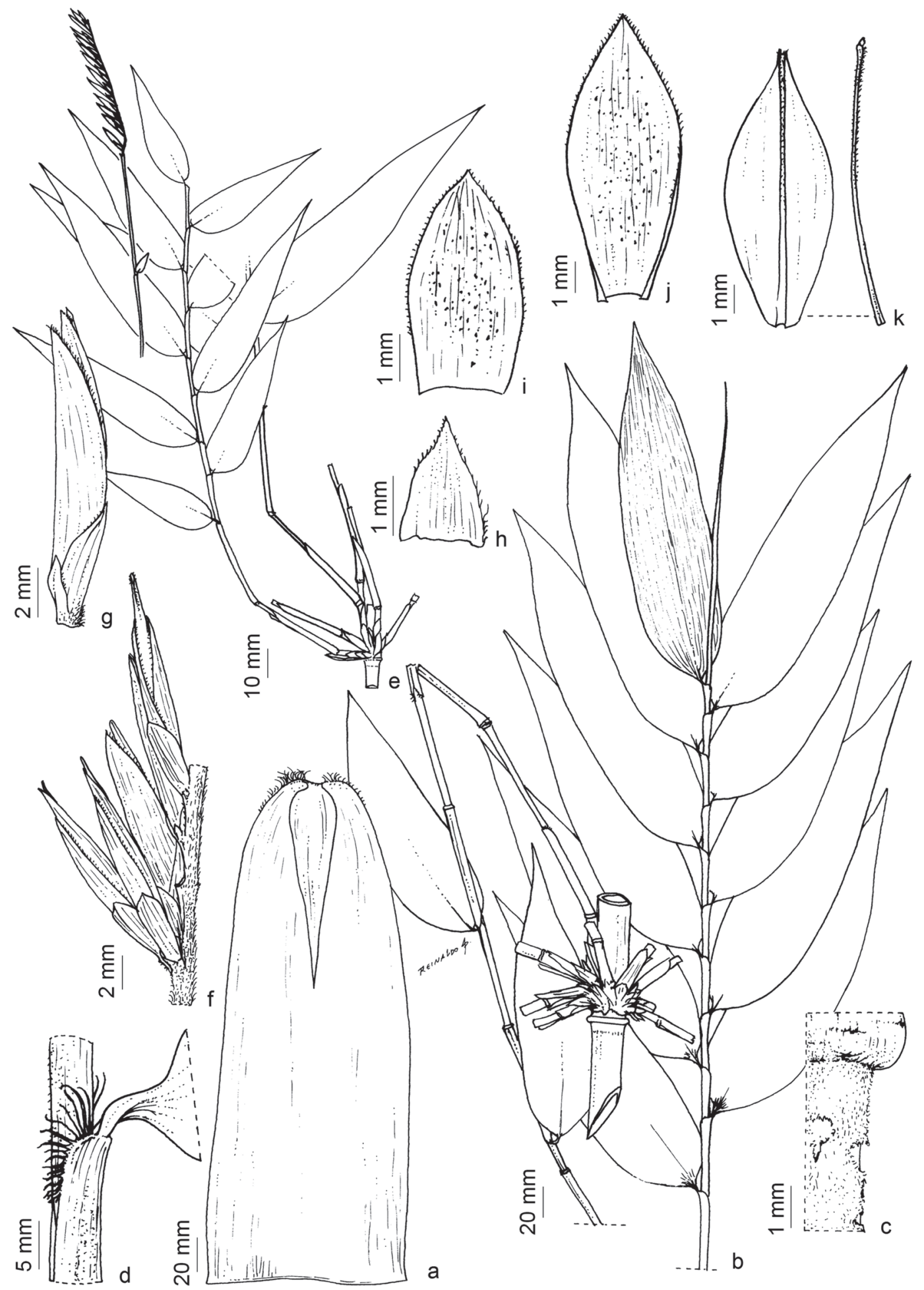

Figura 17. Merostachys ximenae. a-d. (A.P. Santos-Gonçalves et al. 196). e-k. (Parma \& Celso Antônio 44). a. Folha do colmo. b. Complemento de ramo com ramos vegetativos e folhas. c. Faixa infranodal de tricomas lanosos. d. Região ligular da folha do ramo com fímbrias. e. Ramo florífero. f. Seção da inflorescência. g. Espigueta. h. Gluma I. i. Gluma II. j. Lema. k. Pálea e extensão da ráquila. (Ilustrada por Reinaldo Pinto).

Figure 17. Merostachys ximenae. a-d. (A.P. Santos-Gonçalves et al. 196). e-k. (Parma \& Celso Antônio 44). a. Culm leaf. b. Branch complement with vegetative branches and leaves. c. Infranodal band of lanose trichomes. d. Ligular region of foliage leaf with fimbriae. e. Floriferous branch. f. Section of the inflorescence. g. Spikelet. h. Lower glume. i. Upper glume. j. Lemma. k. Palea and rachilla extension. (Illustrated by Reinaldo Pinto). 
membranácea, ápice ciliado; fímbrias presentes, não fusionadas, 3,4-14 mm compr., retas na base e sinuosas no ápice, amareladas a avermelhadas, às vezes amareladas na base e castanhas no ápice; lâmina 6,3-12,3 × 0,5-1,3 cm, face adaxial escabra, face abaxial escabra, margem escabra em direção ao ápice. Complementos de ramos com 10-87 ramos, 50-171,5 cm compr., 2,7-4,8 mm diâm.; ramos de segunda ordem ausentes; nós proeminentes, castanho-escuros a enegrecidos. Folhas dos ramos 8-27 por ramo; bainha 3,4-11 $\mathrm{cm} \times 2,4-13,2 \mathrm{~mm}$, hirsuta a lanosa, às vezes glabra, margem sobreposta ciliada em direção ao ápice; aurículas ausentes; lígula externa 0,2-0,6 mm compr.; lígula interna 0,2-1,6 mm compr., pubescente; fímbrias presentes, não fusionadas, 1-9,3 mm compr., retas a sinuosas, amareladas a avermelhadas, às vezes amareladas na base e avermelhadas em direção ao ápice; pseudopecíolo 3-8,5 mm compr., esverdeado a castanho, reto a retorcido, glabro; lâmina 14,5-27 × 3-6 cm, C:L = 3,2-6,6, lanceolada a oval lanceolada, face adaxial com 2-4 nervuras marginais escabras, ápice escabro, margem oposta com diminutos tricomas estrigosos em direção ao ápice, glabro no restante, face abaxial com uma faixa de diminutos tricomas estrigosos antrorsos em direção ao ápice, próxima à estria discolor, margem oposta híspida, glabra no restante, base assimétrica. Inflorescência pectinada, ca. $7 \mathrm{~cm}$ compr.; pedúnculo subtendido pela bainha da última folha do ramo; raque velutina, bráctea estéril na base do racemo ausente, ca. 26 espiguetas. Espiguetas 11-12,5 × 1,5 mm, agrupadas aos pares, ás vezes solitárias, 1-flora; pedicelo 0,5 $1 \mathrm{~mm}$ compr., velutino; gluma I 2-2,6 × 1-5 mm, 1-nervada, glabra, margem ciliada, mútica; gluma II 4-4,5 × 2,5-3 mm, 8-9-nervada, glabra, margem ciliada em direção ao ápice, mucronada, ângulo obtuso entre gluma II e raque; lema 8-10 × 4-5 mm, 10-13-nervado, opaco, pubérulo, margem ciliada em direção ao ápice, manchas escuras adaxialmente, mútico; pálea 9,5-11 × 3-5 mm, 8-nervada, opaca, pubérula, margem apical ciliada; extensão da ráquila $9-10,5 \mathrm{~mm}$ compr. Cariopse não vista.

Material selecionado: BRASIL. MinAs GerAIs: Lima Duarte, Estrada para Conceição do Ibitipoca, próximo à Cachoeira das Andorinhas, 16-IV-1992, veg., R.C. Oliveira, M.C.M. Garcia \& L.P. Oliveira 87 (Type) (CESJ); Marliéria, Parque Estadual do Rio Doce, Estrada da Ponte-Queimada, 24-VIII-1999, veg., A.P. Santos-Gonçalves et al.196 (Type) (VIC); Viçosa,
Fazenda Bom Sucesso, Mata do Sr. Nico, 12-IX-2014, fl., D.F. Parma \& Celso Antônio 44 (Type) (ISC, MO, $\mathrm{RB}, \mathrm{SP}, \mathrm{VIC})$.

Merostachys ximenae assemelha-se a $M$. annulifera Send. por apresentar os nós do colmo e dos ramos proeminentes; difere, no entanto, por apresentar entrenós e folhas do colmo lanosos e complementos de ramos com 10-87 ramos, ao passo que $M$. annulifera apresenta entrenós e folhas do colmo escabros e complemento de ramo com 5-25 ramos.

Em Minas Gerais, aproxima-se de Merostachys aff. burmanii e $M$. ternata pela presença de espiguetas agrupadas. Merostachys ximenae difere de Merostachys aff. burmanii, pela presença de uma faixa infranodal de tricomas lanosos e de nós dos colmos e dos ramos proeminentes. Os caracteres que diferem $M$. ximenae de $M$. ternata já foram discutidos nos comentários desta última espécie.

Fenologia de floração: Merostachys ximenae foi coletada com flor em 2014, não sendo possível mensurar o seu ciclo de reprodutivo.

Distribuição: a espécie é registrada apenas para Minas Gerais, onde ocorre em sua região Sudeste (Parma et al. 2016a), em sub-bosque e borda de vegetação caracterizada por Veloso et al. (1991) como Floresta Atlântica Estacional Semidecidual Montana e Floresta Atlântica Estacional Semidecidual Submontana.

\section{Merostachys aff. riedeliana.}

Figura $18 \mathrm{a}-\mathrm{b}$

Plantas arborescentes. Colmos 3-15 m compr. Entrenós 11-60 cm compr., verdes com estrias amarelas, glabros a escabros; faixa infranodal de tricomas ausentes; nós não proeminentes. Complementos de ramos com 20-87 ramos, 19,5-104 cm compr.; nós não proeminentes. Folhas dos ramos 6-16 por ramo; aurículas ausentes; fímbrias presentes, não fusionadas; lâmina $6,5-22,5 \times 1,3-4,7 \mathrm{~cm}$, face abaxial com um tufo de tricomas híspidos na base.

Material examinado: BRASIL. Minas Gerais: Araponga, Parque Estadual da Serra do Brigadeiro, trilha do Carvão, 9-IX-2013, veg., M.M. Picanço, D.F. Parma \& E.P. Machado 25 (VIC); Madre de Deus, Alto Rio Grande, 27-III-1998, fl., F.A.G. Guilherme \& K. Ressel 171 (ESAL, VIC).

Merostachys aff. riedeliana assemelha-se a $M$. riedeliana e $M$. claussenii var. claussenii, e as semelhanças e diferenças entre essas espécies já foram discutidas nos comentários de ambas. 


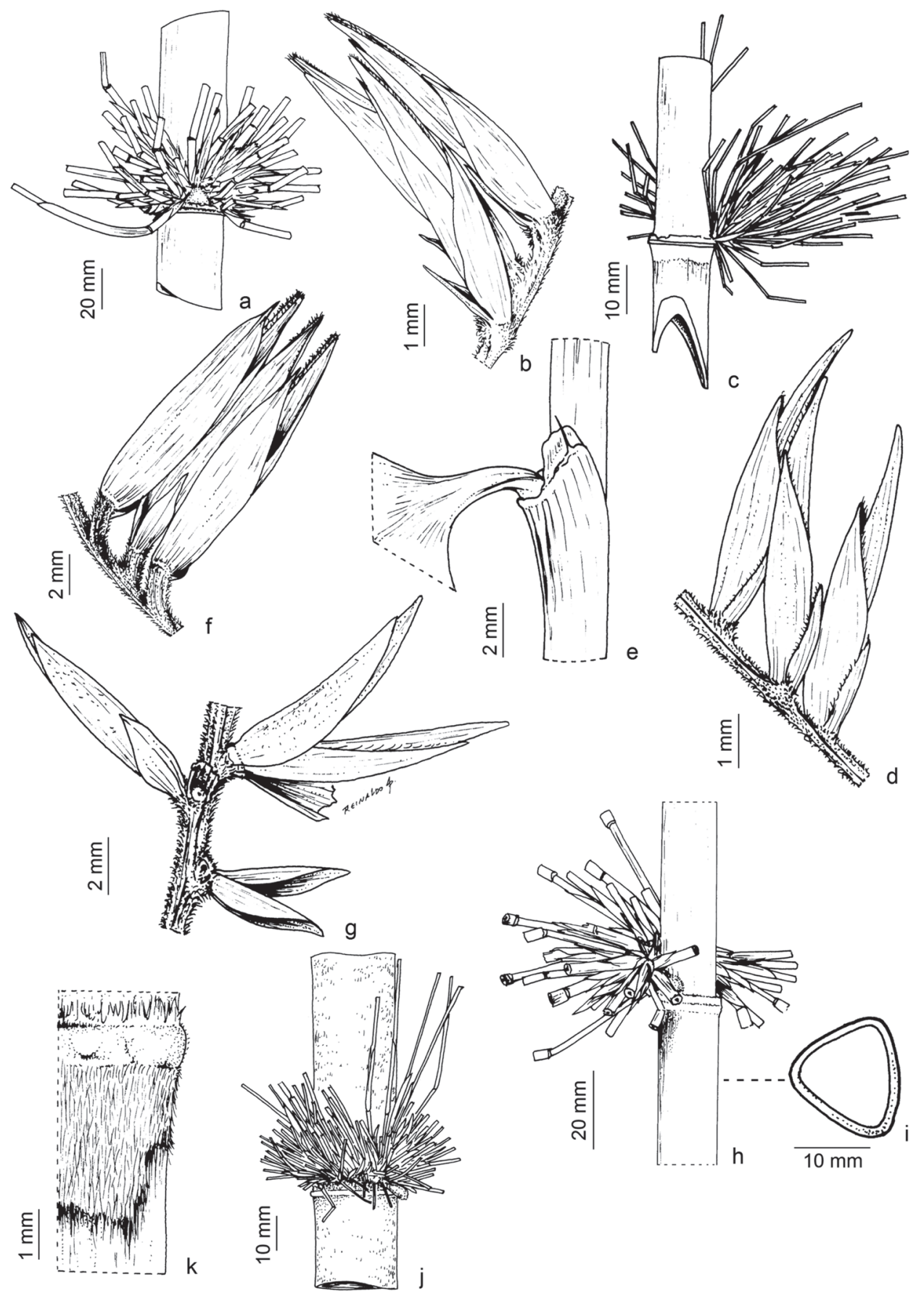

Figura 18. a-b. Merostachys aff. riedeliana. a. (Picanço et al. 25). Complemento de ramo. b. (Guilherme \& Ressel 171). Seção da inflorescência. c-d. Merostachys aff. fischeriana (Krieger \& Leíse s.n. IAC32710). c. Complemento de ramo. d. Seção da inflorescência. e-f. Merostachys aff. fistulosa. (Schwartsburd et al. 2877). e. Região ligular da folha do ramo com uma única fímbria. f. Seção da inflorescência. g. Merostachys aff. burmanii (R.V. Silva et al. 22). Seção da inflorescência. h-i. Merostachys aff. speciosa (A.P. Santos-Gonçalves et al. 201). h. Complemento de ramo. i. Seção transversal do entrenó do mediocolmo com formato subtriangular. j-k. Merostachys aff. petiolata (R.V. Silva et al. 37). j. Complemento de ramo. k. Faixa infranodal de tricomas velutinos. (Ilustrada por Reinaldo Pinto).

Figure 18. a-b. Merostachys aff. riedeliana. a. (Picanço et al., 25). Branch complement. b. (Guilherme \& Ressel 171). Section of the inflorescence. c-d. Merostachys aff. fischeriana (Krieger \& Leise s.n. IAC32710). c. Branch complement. d. Section of the inflorescence. e-f. Merostachys aff. fistulosa. (Schwartsburd et al. 2877). e. Ligular region of the foliage leaf with single fimbriae. f. Section of the inflorescence. g. Merostachys aff. burmanii (R.V. Silva et al. 22). Section of the inflorescence. h-i. Merostachys aff. speciosa (A.P. SantosGonçalves et al. 201). h. Branch complement. i. Cross section of the mid-culm with subtriangular shape. j-k. Merostachys aff. petiolata (R.V. Silva et al. 37). j. Branch complement. k. Infranodal band of velutinous trichomes. (Illustrated by Reinaldo Pinto). 
Fenologia de floração: Merostachys aff. riedeliana foi coletada com flor em 1998 e 2003, não sendo possível estimar o seu ciclo reprodutivo.

Distribuição: distribui-se pelas regiões Sul e Sudeste de Minas Gerais, onde é encontrada em sub-bosque e borda de vegetação caracterizada por Veloso et al. (1991) como Floresta Atlântica Estacional Semidecidual Montana.

\section{Merostachys aff. fischeriana.}

Figura 18c-d

Plantas arborescentes. Colmos 8-10 m compr. Entrenós incompletos, cilíndricos, glabros, lustrosos; faixa infranodal de tricomas presente. Nós não proeminentes. Complementos de ramos com 83-170 ramos, 0,5-0,9 mm diâm.; ramos de segunda ordem ausentes; nós não proeminentes. Folhas dos ramos 5-14 por ramo; fímbrias presentes, não fusionadas; lâmina com face adaxial glabra, sem uma faixa de diminutos tricomas estrigosos em direção ao ápice, próxima à estria discolor, tufo de tricomas híspidos na base presente. Inflorescência com pedúnculo subtendido pela bainha da última folha do ramo, bráctea estéril na base ausente. Espiguetas 4-7 mm compr., 1-flora.

Material examinado: BRASIL. Minas Gerais: Alto Caparaó, Parque Nacional do Caparaó, Vale Verde, 27-IX-1977, fl., L. Krieger \& Leíse s.n. (IAC32710).

Merostachys aff. fischeriana assemelha-se a $M$. fischeriana, e as características que as aproximam e distinguem já foram discutidas nos comentários desta espécie.

Fenologia de floração: Merostachys aff. fischeriana foi coletada com flor apenas em 1977, não sendo possível estimar seu ciclo reprodutivo.

Distribuição: Merostachys aff. fischeriana é registrada para o Sudeste de Minas Gerais, onde foi coletada, até o momento, apenas no Parque Nacional do Caparaó. Os dados relacionados ao hábitat são inexistentes no material examinado.

\section{Merostachys aff. fistulosa.}

Figura $18 \mathrm{e}-\mathrm{f}$

Plantas arborescentes. Colmos ca. $10 \mathrm{~m}$ compr. Entrenós cilíndricos, verdes com estrias amarelas, escabros com tricomas seríceos próximo aos nós; faixa infranodal de tricomas ausente; lúmen não preenchido por medula; parede 1,2-4,2 $\mathrm{mm}$ de espessura. Franja de tricomas na linha nodal ausente. Complementos de ramos com 7-40 ramos, com 1,6-2,3 mm diâm. Folhas dos ramos 4-18 por ramo; aurículas ausentes; fímbrias presentes, não fusionadas, escassas; lâmina com face abaxial sem tufo de tricomas híspidos na base. Espiguetas 13-16 mm compr., solitárias.

Material examinado: BRASIL. Minas Gerais: São Gonçalo do Rio Preto, Parque Estadual do Rio Preto, 7-XII-2013, fl., P.B. Schwartsburd, A.P. FortunaPerez, I. Becari-Viana, L.G.M. Vieira \& E.S. Cândido 2877 (VIC).

Merostachys aff. fistulosa caracteriza-se, principalmente, pela presença de fímbrias escassas e diminutas em algumas folhas dos ramos; na maioria das folhas observa-se a ausência das fímbrias. Aproxima-se de M. fistulosa por apresentar entrenós escabros, verdes e com estrias amarelas. Difere, no entanto, pela presença de fímbrias em algumas folhas dos ramos e pelo comprimento da espigueta.

Fenologia de floração: foi registrada com flor apenas em 2013, não sendo possível estimar o seu ciclo reprodutivo.

Distribuição: Merostachys aff. fistulosa tem sua ocorrência, até então, restrita ao Parque Estadual do Rio Preto, região Central de Minas Gerais, onde ocorre em borda de vegetação caracterizada por Veloso et al. (1991) como Floresta Atlântica Estacional Semidecidual Montana.

\section{Merostachys aff. burmanii.}

Figura $18 \mathrm{~g}$

Plantas arborescentes. Colmos 5-20 m compr. Entrenós cilíndricos, escabros; faixa infranodal de tricomas ausente; parede 1-4 mm de espessura; lúmen não preenchido por medula. Franja de tricomas na linha nodal presente. Complementos de ramos com 30-171 ramos, 1,1-2 mm diâm. Folhas dos ramos 6-20 por ramo; aurículas ausentes; fímbrias presentes, não fusionadas; lâmina com face abaxial sem um tufo de tricomas híspidos na base. Inflorescência não pectinada. Espiguetas 8,5-9 mm compr., agrupadas aos pares ou em tríades, às vezes solitárias, lema setoso.

Material examinado: BRASIL. MinAs GeraIs: Santa Maria do Salto, Parque Estadual Alto Cariri, Areia Branca, Refúgio da Vida Silvestre Mata dos Muriquis, 13-V-2014, fl., R.V. Silva, J.I. Silva, J.V. Nunes, R.B. Sansão \& W.O. Marques 22 (VIC).

Merostachys aff. burmanii aproxima-se, principalmente, de Merostachys burmanii Send. 
pela presença de inflorescências não pectinadas, raque sinuosa e espiguetas agrupadas aos pares ou em tríades, ás vezes solitárias. Difere, no entanto, pela ausência de uma faixa infranodal de tricomas e por apresentar lema setoso e entrenós escabros, enquanto $M$. burmanii apresenta uma faixa infranodal de tricomas, lema pubescente e entrenós glabros a escabros.

Em Minas Gerais, Merostachys aff. burmanii é próxima de Merostachys ximenae e M. ternata por apresentar espiguetas agrupadas. Os caracteres que a difere destas espécies já foram discutidos nos seus respectivos comentários.

Fenologia de floração: Merostachys aff. burmanii foi coletada em estádio reprodutivo em 2003 e 2014. Apesar de escassos, estes registros de floração sugerem um ciclo reprodutivo de 11 anos.

Distribuição: Merostachys aff. burmanii é registrada para a região Nordeste de Minas Gerais, onde ocorre no sub-bosque e borda de vegetação caracterizada por Veloso et al. (1991) como Floresta Atlântica Estacional Semidecidual Montana.

\section{Merostachys aff. speciosa.}

Figura 18h-i

Plantas arborescentes. Colmos 12-15 m compr., região mediana com formato subtriangular. Entrenós glabros a escabros; faixa infranodal de tricomas presente. Nós não proeminentes. Complementos de ramos com 6-40 ramos; ca 3 ramos de segunda ordem presentes, 12,5-24 cm compr., nós não proeminentes. Folhas dos ramos 6-15 por ramo; fímbrias presentes, não fusionadas, esbranquiçadas, retas na base e sinuosas em direção ao ápice; lâmina escabra na superfície abaxial. Inflorescências não vistas.

Material examinado: BRASIL. Minas Gerais: Marliéria, Parque Estadual do Rio Doce, trilha da Lagoa do Meio, 21-IX-1999, veg., A.P. SantosGonçalves et al. 201 (VIC).

Merostachys aff. speciosa se assemelha a Merostachys speciosa Spreng. pela pilosidade do entrenó; presença de fímbrias esbranquiçadas, retas na base e sinuosas em direção ao ápice; comprimento e largura da lâmina das folhas dos ramos e pilosidade da superfície abaxial das lâminas das folhas dos ramos. Distingue-se, no entanto por apresentar uma faixa infranodal de tricomas e região mediana do colmo com formato subtriangular, enquanto $M$. speciosa não possui uma faixa infranodal de tricomas e possui colmo cilíndrico.
Fenologia de floração: Merostachys aff. speciosa foi coletada, até o momento, apenas em estádio vegetativo.

Distribuição: Merostachys aff. speciosa é registrada para a região Sudeste de Minas Gerais, onde é encontrada em sub-bosque de vegetação caracterizada por Veloso et al. (1991) como Floresta Atlântica Estacional Semidecidual Submontana.

\section{Merostachys aff. petiolata.}

Figura $18 \mathrm{j}-\mathrm{k}$

Plantas arborescentes. Colmos 8-15 m compr. Entrenós cilíndricos, verde com estrias amarelas, escabros, opacos, região supranodal serícea; faixa infranodal de tricomas presente. Folhas do colmo com bainha glabra na superfície abaxial. Complementos de ramos com ramos de 0,9-1,7 mm diâm. Folhas dos ramos 6-13 por ramo; fímbrias presentes, não fusionadas, 1,11-11,74 mm compr., amareladas a castanhas; lâmina 5-14,7 ×0,83-2,37 cm, com face adaxial apresentando 3 nervuras marginais escabras, região oposta glabra, sem diminutos tricomas estrigosos antrorsos em direção ao ápice, face abaxial com uma faixa de diminutos tricomas estrigosos em direção ao ápice próximo à estria discolor, glabra no restante.

Material examinado: BRASIL. Minas Gerais: Aiuruoca, Água Preta, Estrada Alagoa-Aiuruoca, Ponte da Água Preta, 25-VI-2014, veg., R.V. Silva, M.A. Cupertino \& J.F. Ferreira 37 (VIC).

Merostachys aff. petiolata aproxima-se de Merostachys petiolata Döll pelo comprimento e diâmetro da lâmina das folhas dos ramos, diâmetro dos ramos do complemento de ramos, comprimento e coloração das fímbrias, pilosidade e coloração do entrenó e pela presença de uma faixa infranodal de tricomas. Difere-se, no entanto, pela presença de folhas do colmo com bainha glabra na superfície abaxial e lâmina das folhas dos ramos glabra com um tufo de tricomas na base da superfície abaxial, enquanto $M$. petiolata possui a superfície abaxial da bainha da folha do colmo escabra e a da lâmina da folha dos ramos híspida.

Fenologia de floração: Merostachys aff. petiolata foi coletada, até o momento, apenas em estádio vegetativo.

Distribuição: Merostachys aff. petiolata é registrada para a região Sul de Minas Gerais, onde foi coletada 
em sub-bosque e borda de vegetação caracterizada por Veloso et al. (1991) como Floresta Atlântica Estacional Semidecidual Montana.

\section{Agradecimentos}

Os autores agradecem ao Conselho Nacional de Desenvolvimento Científico e Tecnológico (CNPq 563545/2010-0-REFLORA) pelo apoio financeiro; ao José Ilton da Silva, Edley André da Silva, Luís Carlos da Silva, Valdir Maria, Maurício Teixeira, Clever Coelho, Mônica A. Cupertino Eisenlohr e Alaísma Pereira da Silva pelo auxílio nos trabalhos de campo; ao Reinaldo Pinto pela confecção das ilustrações.

\section{Literatura citada}

BPG. 2012. An updated tribal and subtribal classification of the bamboos (Poaceae: Bambusoideae). Bamboo Science \& Culture 24: 1-10.

Dutra, J. 1938. Les Bambusees de Rio Grande do Sul. Revista Sudamericana de Botánica 5: 145-152.

Flora do Brasil 2020 (em construção). 2016. Poaceae. Jardim Botânico do Rio de Janeiro. Disponível em http:// floradobrasil.jbrj.gov.br/reflora/floradobrasil/FB102232 (acesso em 14-VI-2016).

Greco, T.M. 2013. Diversidade de bambus (Poaceae: Bambusoideae) na Ilha de Santa Catarina, Brasil. Dissertação, Universidade Federal de Santa Catarina, Florianópolis.

Guerreiro, C. 2014. Flowering cycles of woody bamboos native to southern South America. Journal of Plant Research 127: 307-313.

Guilherme, F.A.G. \& Ressel, K. 2001. Biologia floral e sistema de reprodução de Merostachys riedeliana (Poaceae: Bambusoideae). Revista Brasileira de Botânica 24: 205-211.

Janzen, D.H. 1976. Why bamboos wait so long to flower. Annual Review of Ecology and Systematics 7: 374-391.

Judziewicz, E.J., Clark, L.G., Londoño, X. \& Stern, M.J. 1999. American Bamboos. Smithsonian Institution Press, Washington.

Liebsh, D. \& Reginato, M. 2009. Florescimento e frutificação de Merostachys skvortzovii Sendulsky (taquara-lixa) no estado do Paraná. Iheringia. Série Botânica 64: 53-56.

Lizarazu, M.A., Rúgolo-de-Agrasar, Z.E. \& Vega, A.S. 2011. A new species of Merostachys (Poaceae, Bambusoideae, Bambuseae) and synopsis of the genus in Argentina and neighboring regions. Systematic Botany 36: 896-906.

McClure, F.A. 1966. The bamboos: a fresh perspective. Harvard University Press, Cambridge.
McClure, F.A. 1973. Genera of Bamboos native to the New World (Graminae: Bambusoideae). Series Smithsonian Contributions to Botany, n. 9. Smithsonian Institution Press, Washington.

McClure, F.A. \& Smith, L.B. 1967. Gramíneas. In: R. Reitz (ed.). Flora Ilustrada de Santa Catarina. Part. I, Itajaí, Herbário Barbosa Rodrigues, pp. 1-78.

Munro, W. 1868. A monograph of the Bambusaceae, including descriptions of all species. Transactions of the Linnean Society of London 26: 1-157.

Nees, C.G. 1829. Merostachys ternata. In: C.F.P. Martius, Eichler, A.W. \& Urban, I. (eds.). Flora brasiliensis v. 2, part. III, Fasc. 83, pp. 209-210.

Parma, D.F., Pianissola, E.M., Vinícius-Silva, R., Clark, L.G. \& Santos-Gonçalves, A.P. 2016a. Two new species of Merostachys (Poaceae: Bambusoideae) from the Brazilian Atlantic forest. Phytotaxa 267: 219-227.

Parma, D.F., Vinícius-Silva, R., Machado, E.P. \& Santos-Gonçalves, A.P. 2016b. Bambuseae (Poaceae, Bambusoideae) no município de Viçosa, Minas Gerais, Brasil. Hoehnea 43: 387-399.

Renvoize, S.A. 1984. The Grasses of Bahia. Royal Botanical Gardens, Kew.

Santos-Gonçalves, A.P., Carvalho-Okano, R.M., Vieira, M.F. \& Filgueiras, T.S. 2006. Bambus (Bambusoideae: Poaceae) do Parque Estadual do Rio Doce, Minas Gerais: Florística e Taxonomia. In: J.G. Almeida \& A.A. Teixeira (orgs.). Anais do I Seminário Nacional do Bambu: Estruturação da Rede de Pesquisa e Desenvolvimento, Brasília, pp. 43-48.

Santos-Gonçalves, A.P., Carvalho-Okano, R.M. \& Filgueiras, T.S. 2012. A new species of Merostachys (Poaceae: Bambusoideae) from Southeastern Brazil. Systematic Botany 37: 938-940.

Schmidt, R. \& Longhi-Wagner, M.H. 2009. A tribo Bambuseae (Poaceae, Bambusoideae) no Rio Grande do Sul. Revista Brasileira de Biociências 7: 71-128.

Sendulsky, T. 1992. Merostachys burmanii (Poaceae: Bambusoideae: Bambuseae), a new species from Brazil. Novon 2: 111-113.

Sendulsky, T. 1995. Merostachys multiramea (Poaceae: Bambusoideae: Bambuseae) and similar species from Brazil. Novon 5:76-96.

Sendulsky, T. 1997. Twelve species of Merostachys (Poaceae: Bambusoideae: Bambuseae) from Brazil. Novon 7: 285-307.

Sendulsky, T. 2001. Merostachys Spreng. (Poaceae, Bambusoideae, Bambuseae): A new species from Brazil and critical notes on "Group Speciosa". Kew Bulletin 56: 627-638. 
Shirasuna, R.T. \& Filgueiras, T.S. 2013. Bambus nativos (Poaceae, Bambusoideae) no Parque Estadual das Fontes do Ipiranga, São Paulo, SP, Brasil. Hoehnea 40: 315-359.

Smith, L.B., Wasshausen, D.C. \& Klein, R.M. 1982. Gramíneas. In: R. Reitz (ed.). Flora Ilustrada Catarinense part. I, Itajaí, Herbário Barbosa Rodrigues, pp. 443-906.

Soderstrom, T., R. \& Young, S. M. 1983. A Guide to Collecting Bamboos. Annals of the Missouri Botanical Garden 70: 128-136.

Teixeira, R.G., Carniello, M.A., Guarim Neto, G. \& Souza, F.P. 2007. Poaceae - Subfamília Bambusoideae: espécies catalogadas para o estado do Mato Grosso, Brasil. Revista Brasileira de Biociências 5: 1086-1088.

Thiers, B. 2015. Index Herbariorum: A global directory of public herbaria and associated staff. New York Botanical Garden's Virtual Herbarium. Disponível em http://sweetgum.nybg.org/science/ih/ (acesso em 23-XII-2016).
Tyrrell, C.D., Santos-Gonçalves, A. P., Londoño, X. \& Clark, L.G. 2012. Molecular phylogeny of the arthrostylidioid bamboos (Poaceae: Bambusoideae: Bambuseae) and new genus Didymogonyx. Molecular Phylogenetics and Evolution 65: 136-148.

Veloso, H.P., Rangel Filho, A.L.R. \& Lima, J.C.A. 1991. Classificação da vegetação brasileira adaptada a um sistema universal. Fundação Instituto Brasileiro de Geografia e Estatística (IBGE), Departamento de Recursos Humanos e Estudos Ambientais, Rio de Janeiro.

Vinícius-Silva, R., Cupertino-Eisenlohr, M.A., Clark, L.G. \& Santos-Gonçalves, A.P. 2016. Two New Species of Merostachys (Poaceae: Bambusoideae: Bambuseae: Arthrostylidiinae) from Minas Gerais State, Brazil. Systematic Botany 41: 959-965.

Viana, P.L. \& Filgueiras, T.S. 2008. Inventário e distribuição geográfica das gramíneas (Poaceae) na Cadeia do Espinhaço, Brasil. Megadiversidade 4: 71-88. 